\title{
1 Forest decision support systems for the analysis of ecosystem services 2 provisioning at the landscape scale under global climate and market 3 change scenarios
}

Eva-Maria Nordström ${ }^{1 *}$, Maarten Nieuwenhuis ${ }^{2 *}$, Emin Zeki Başkent ${ }^{3}$, Peter Biber ${ }^{4}$, Kevin Black ${ }^{2}$, Jose G. Borges $^{5}$, Miguel N. Bugalho ${ }^{6}$, Giulia Corradini ${ }^{7}$, Edwin Corrigan ${ }^{2}$, Ljusk Ola Eriksson ${ }^{1}$, Adam Felton ${ }^{8}$, Nicklas Forsell ${ }^{9}$, Geerten Hengeveld ${ }^{10}$, Marjanke Hoogstra-Klein ${ }^{10}$, Anu Korosuo ${ }^{9}$, Matts Lindbladh ${ }^{8}$, Isak

8 Lodin $^{8}$, Anders Lundholm ${ }^{2}$, Marco Marto ${ }^{5}$, Mauro Masiero ${ }^{7}$, Gintautas Mozgeris ${ }^{11}$, Davide Pettenella ${ }^{7}$,

9 Werner Poschenrieder ${ }^{4}$, Robert Sedmak ${ }^{12,13}$, Jan Tucek ${ }^{12}$ and Davide Zoccatelli ${ }^{7,14}$

*Corresponding authors.

E-MN. Address: Department of Forest Resource Management, Swedish University of Agricultural Sciences (SLU), 90183 Umeå, Sweden. Telephone: +46 (0)90 7868258. Email: eva-maria.nordstrom@slu.se MN. Address: UCD Forestry, School of Agriculture and Food Science, University College Dublin, Belfield, Dublin 4, Ireland. Telephone: +353 (0)1 7167004. Email: maarten.nieuwenhuis@ucd.ie

${ }^{1}$ Department of Forest Resource Management, Swedish University of Agricultural Sciences (SLU), 90183 Umeå, Sweden. Email: eva-maria.nordstrom@slu.se, ola.eriksson@slu.se maarten.nieuwenhuis@ucd.ie, kevin.g.black@gmail.com,edwint.corrigan@gmail.com, anders.lundholm@ucdconnect.ie ${ }^{3}$ Faculty of Forestry, Karadeniz Technical University, 61080 Trabzon, Turkey. Email: eminzekibaskent@gmail.com ${ }^{4}$ Chair of Forest Growth and Yield Science, TUM School of Life Sciences Weihenstephan, Technical University of Munich (TUM), Hans-Carl-von-Carlowitz-Platz 2, Freising 85354, Germany. Email: peter.biber@Irz.tum.de, werner.poschenrieder@Irz.tum.de ${ }^{5}$ Forest Research Centre, School of Agriculture, University of Lisbon, Tapada da Ajuda, Lisbon 1349-017, Portugal. Email: joseborges@isa.ulisboa.pt, marcovmarto@isa.ulisboa.pt 1349-017, Portugal. Email: migbugalho@isa.ulisboa.pt giulia.corradini@unipd.it, mauro.masiero@unipd.it, davide.pettenella@unipd.it, zoccatelli.davide@gmail.com ${ }^{8}$ Southern Swedish Forest Research Centre, Swedish University of Agricultural Sciences (SLU), Box 49, 23053 Alnarp, Sweden. Email: adam.felton@slu.se, matts.lindbladh@slu.se, isak.lodin@slu.se ${ }^{9}$ Ecosystem Services and Management Program, International Institute for Applied Systems Analysis (IIASA), Schlossplatz 1, A-2361 Laxenburg, Austria.Email: forsell@iiasa.ac.at, korosuo@iiasa.ac.at 6708PB Wageningen, the Netherlands. Email: geerten.hengeveld@wur.nl, marjanke.hoogstra@wur.nl Akademija, Lithuania. Email: gintautas.mozgeris@asu.It

$40 \quad{ }^{12}$ Department of Forest Management and Geodesy, Technical University in Zvolen, T.G. Masaryka 24, Zvolen 960 41 53, Slovakia. Email: sedmak@tuzvo.sk, tucek@tuzvo.sk 
$42{ }^{13}$ Department of Forest Management, Czech University of Life Sciences Prague, Kamýcká 1176, 16521 Prague 6-

43 Suchdol, Czech Republic

$44{ }^{14}$ Institute of Earth Sciences, The Edmond J. Safra Campus - Givat Ram, Hebrew University of Jerusalem, Jerusalem 45 9190401, Israel

\section{Acknowledgements}

47 This project has received funding from the European Union's Horizon 2020 research and innovation

48 programme under grant agreement No 676754. We further acknowledge the Portuguese Science

49 Foundation (FCT) for supporting Miguel Bugalho by a Principal Investigator contract (IF/01171/2014), for

50 funding the Forest Research Centre (UID/AGR/00239/2013) and for the Ph.D. grant of Marco Marto

51 (SFRH/BD/108225/2015). 


\section{Abstract}

53 Sustainable forest management is driving the development of forest decision support systems (DSSs) to

54 include models and methods concerned with climate change, biodiversity and various ecosystem

55 services (ESs). The future development of forest landscapes is very much dependent on how forest

56 owners act and what goes on in the wider world, thus models are needed that incorporate these

57 aspects. The objective of this study is to assess how nine European state-of-the-art forest DSSs cope

58 with these issues. The assessment focuses on the ability of these DSSs to generate landscape level

59 scenarios to explore the output of current and alternative forest management models (FMMs) in terms

60 of a range of ESs and the robustness of these FMMs in the face of increased risks and uncertainty.

61 Results show that all DSSs assessed in this study can be used to quantify the impacts of both stand and

62 landscape-level FMMs on the provision of a range of ESs over a typical planning horizon. DSSs can be

63 used to assess how timber price trends may impact that provision over time. The inclusion of forest

64 owner behavior as reflected by the adoption of specific FMMs seems to be also in the reach of all DSSs.

65 Nevertheless, some DSSs need more data and development of models to estimate the impacts of

66 climate change on biomass production and other ESs. Spatial analysis functionality need to be further

67 developed for a more accurate assessment of the landscape level output of ESs from both current and

68 alternative FMMs.

69 Keywords: ALTERFOR, biodiversity, forest management models, forest owner behaviour

\section{Introduction}

71 Ecosystem Services (ESs) are the benefits that humans obtain from ecosystems (Millennium Ecosystem

72 Assessment 2005). Since the ES concept includes economic, ecological as well as social values of nature,

73 it can be a used as tool for decision and policy making concerning sustainable resource management.

74 Ecosystem service delivery is strongly dependent on ecosystem management and frequently implies 
75 trade-offs among services (Bugalho et al. 2011, 2016). However, to allow for the analysis of trade-offs

76 and effects of land use and management on the provision of ES, the ES concept needs to be

77 operationalized through quantitative assessments based on mapping and modelling (Seppelt et al. 2011;

78 Borges et al. 2014a; Andrew et al. 2015).

79 Even before ESs became a widely known concept, forest management was concerned with assessing the 80 benefits produced by forests under different kind of management (Grêt-Regamey et al. 2016; Kindler

81 2016). Since the start of modern forestry, forest management has mainly focused on wood production

82 and on how to manage forests efficiently for a sustainable yield of wood. However, multiple-use forestry

83 has long been practiced and was formally introduced already in the 1960s in the US (Hoogstra-Klein et

84 al. 2017). Later, the concept of sustainable forest management emphasized the need for inclusion of

85 ecological and social aspects and consideration of future generations (United Nations 1992). In the past

8630 years, advanced forest decision support systems (DSS) have been developed to enable analysis of

87 complex problems related to forest management (Reynolds et al. 2008; Borges et al. 2014b). A forest

88 DSS is a software system that can be used for modelling of forest development based on both biological

89 processes and management effects over long time horizons. Though many forest DSSs were initially

90 developed with a strong focus on wood production, the wider perspective required in the analysis of

91 sustainable forest management is driving the development of DSSs to include models and methods

92 concerned with, e.g., climate change, biodiversity and various ESs (Borges et al. 2014b; Vacik and Lexer

93 2014).

94

95 A number of studies have addressed the question of how forest DSSs can be used to assess the future

96 provisioning of ESs. Some of the earliest examples are from the US where DSSs for ecosystem

97 management were developed to support forest management aimed at production of goods and services

98 as well as maintaining ecosystem structures and functions (Rauscher 1999; Reynolds 2005). The Forest 
99 Planning Model (FORPLAN) was developed in the late 1970s to support planning for multiple use and

100 sustained yield of goods and services (Kent et al. 1991). NED (Twery et al. 2005) and the Ecosystem

101 Management Decision Support (EMDS) system (Rauscher 1999; Reynolds 2005) was then developed by

102 the USDA Forest Service, starting some 20 years ago.

103

104 In a more recent study, Biber et al. (2015) analyzed the effects of forest management intensity on ESs

105 delivery by compiling information from case studies in ten European countries where ten different DSSs

106 were used for scenario analysis. The results showed that there was an obvious strong positive

107 correlation between management intensity and wood production. However, for biodiversity the

108 correlation with management intensity depended on the forest region in which the case study area was

109 located. In some forest regions there was a trade-off between biodiversity and management intensity,

110 but in others a positive correlation between biodiversity and more intense management was found. For

111 other ESs, the correlation with management intensity was only weak and negative. For instance, there

112 was no clear trend for the relationship between non-wood products (mushrooms, cork, pine cones and

113 grazing) and management intensity. Further, Biber et al. (2015) concluded that local data and DSSs are a

114 useful complement to large-scale studies since they provide the most accurate and relevant information

115 available on a local level. The reader is referred to Corrigan and Nieuwenhuis (2017), Borges et al. (2017)

116 and Hengeveld et al. (2015) for a detailed description of how three of these DSSs were used to assess a

117 wide range of ESs in case study areas in Ireland and Portugal. Further, in their review of the same ten

118 DSSs included in Biber et al. (2015), Orazio et al. (2017) pointed out that even though the set of DSSs is

119 diverse, all of these DSSs can take ecological and socioeconomic conditions into account, in one way or

120 another. However, modelling of tree development and wood production output are still the strongest

121 parts in the DSSs and there is a need to develop the modelling to include indicators for other ESs and

122 biodiversity. Further, only some of the DSSs were able to include climate effects on forest growth and 
123 most do not include other land uses. Most DSSs are thus well suited for current conditions but need

124 further development to be useful under a changing climate as well as under new, alternative forest

125 management regimes. This is in line with conclusions from more general reviews of DSSs in forest

126 management (Reynolds et al. 2008; Muys et al. 2010; Vacik and Lexer 2014).

128 The studies mentioned above focus mainly on scenarios describing the development of the forest over

129 time, given biological processes such as growth and mortality, and the effects of harvesting and

130 silvicultural activities on the delivery of ESs and biodiversity conservation, i.e., the supply side. The

131 demand for ESs is rarely explicitly considered in these scenarios. However, the future development of a

132 forest landscape is very much dependent on what goes on in the world around this landscape. Drivers

133 like economic development, population growth and climate change will affect the demand for various

134 ESs and should also be considered at the landscape level. There are scenarios that could be used for this

135 type of analysis; for instance, the fifth Assessment Report of the Intergovernmental Panel on Climate

136 Change (IPCC) has set up a scenario framework which allows for global analysis of climate change

137 impacts and mitigation options under different socioeconomic development and covers a wide range of

138 potential future trajectories for global development of climate change, economic growth, population

139 development and overall use of natural resources (IPCC 2013, 2014a, b).

141 Furthermore, even projecting the forest development subject to external drivers is not sufficient when

142 scenarios are supposed to reflect management responses on landscape level to various policies, climate

143 change and market developments. The forest owner behavior as a response to policy, climate change,

144 changing prices for forest products and other stakeholders will in many cases be an important factor

145 that needs to be considered in the analysis (Mozgeris et al. 2016; Rinaldi et al. 2015). 
147 The challenges in including ESs and biodiversity in scenario analysis using forest DSSs that have been

148 highlighted above are in line with general issues that have been identified as problematic in ESs

149 assessment for decision support: i) use of simplistic approaches due to lack of data and realistic models,

150 ii) focus on only a limited number of ESs, often due to a lack of information on others despite their

151 relevance to decision making, iii) precision, accuracy and uncertainties in assessments are not dealt

152 with, and iv) that the demand for ESs is rarely considered since this usually requires an interdisciplinary

153 approach (Eigenbrod et al. 2010; Seppelt et al. 2011; Wolff et al. 2015; Grêt-Regamey et al. 2016).

155 The objective of this study is to assess how a number of European state-of-the-art (i.e., the highest level

156 of general development achieved in each country) forest management planning DSSs cope with

157 modeling of ESs. The assessment will focus on the ability of these DSSs to generate landscape level

158 scenarios to explore the output of current and alternative silvicultural approaches and forest

159 management models (FMMs) in terms of a range of ESs and the robustness of these FMMs in the face of

160 increased risks and uncertainty. With this general objective in view, this study more specifically aims to:

161

$162 \quad-\quad$ evaluate the capacity of forest DSSs to project the output of ESs over time at the landscape

163 level, under different global climate change and market scenarios and taking forest owner

164 behaviour into account, and

165 - highlight needs for the further development of DSSs and propose approaches that could be used

166 to improve modelling.

\section{Material and methods}

168 Assessment of DSSs 
170 forest management and investigates how they can be used to analyze the impacts of different FMMs on

171 the provisioning of ESs in a range of forest landscapes in nine European countries (Germany, Ireland,

172 Italy, Lithuania, Netherlands, Portugal, Slovakia, Sweden and Turkey). These DSSs are all part of the

173 European Union project ALTERFOR (www.alterfor-project.eu), in which they will be used to examine

174 currently used and alternative FMMs in case study areas in each country and the potential to optimize

175 the forest management with regard to ES provisioning in different European countries. The case study

176 areas are briefly presented in Table 2, including some information on the main ESs and stakeholders in

177 each case study area. The assessment of the DSSs in this study is based on the properties of the DSSs

178 rather than the results from applying the DSSs in the case studies to create scenarios. However,

179 investigating how a DSS handles different ESs requires a context in which the DSS operates, i.e., a

180 landscape in which certain ESs are important and could be quantified in certain ways. Thus, in this study

181 the function of the case studies was to provide a range of forest landscapes with different focuses on ES

182 provision and different stakeholders as a background for the assessment of the DSSs.

183

184 [INSERT TABLE 1 AROUND HERE]

185 [INSERT TABLE 2 AROUND HERE\}

186

187 More specifically, by forest DSS we mean a software system used for analysis pertaining to the domain

188 of forest management. Thus, it includes stand simulators, growth and yield models, and associated tools

189 that are integrated into systems that make landscape projections for management planning. However, it

190 does not encompass general purpose software systems like Microsoft Excel or GIS software, unless the

191 DSS is implemented on those platforms. With this definition, a mere transfer of data from the DSS to a

192 GIS for calculating an index does not make the GIS part of the DSS as the term is used here. 
194 In the analysis of future output of ESs under various FMMs, the capability to include information on 195 climate change and socioeconomic development from global scenarios as well as the behavior of forest 196 owners at landscape level are important elements. Specific properties that are critical for DSSs to be 197 able to handle these requirements were formulated based on existing knowledge and experiences from 198 the INTEGRAL project (e.g., Biber et al. 2015; Orazio et al. 2017) and other studies (Muys et al. 2010; 199 Vacik and Lexer 2014). These properties are:

200 1) capability to deal with changing market prices over time for timber and biomass assortments;

201 2) capability to include climate change effects in landscape level scenarios;

202 3) the spatial specificity of the landscape scale analyses (i.e., the extent to which location of and 203 spatial relationships between forest stands is known);

4) inclusion of forest owner behaviour, in terms of the existing FMMs that different owner types

206 More detailed descriptions of these properties are presented in the section "Specific DSS properties 207 considered in the assessment". These were defined by the authors in collaboration with researchers 208 within the ALTERFOR project.

210 Information on the critical properties of the DSSs was solicited from researchers working with the 211 systems in a number of steps. Initially, a questionnaire was sent out, in which a description of each DSS 212 (Table 1) and their capabilities was requested based on a series of targeted questions. The information 213 requested related both to the current status of the DSS at that time and to the developments that were 214 planned to improve the DSS, referring to the specific properties mentioned above. These questionnaires 215 were followed-up with telephone interviews that allowed for further discussion of missing or incomplete 
answers. A follow up request for information was sent out six months later and the researchers were

217 asked to report on the progress in DSS development and indicate if and how their respective DSSs

218 included the four properties listed above. This information, together with the earlier questionnaires,

219 provided a structure for the reporting of the results in this paper. Based on the comprehensive

220 information resulting from this process, a more detailed analysis was carried out to identify those

221 properties and ESs for which proper DSS design solutions had been found and, more importantly,

222 properties and ESs which in some DSSs were causing difficulties in terms of proper system integration.

223 The purpose of this analysis was to identify basic commonalities, contrasts and 'best practice' among all

224 DSSs in dealing with the critical properties and the analysis was carried out in collaboration with

225 researchers with expertise on the different ESs.

\section{Ecosystem services considered in the assessment}

227 Many forest DSSs are designed to primarily project the output of timber and other biomass, but with

228 increasing focus on sustainable forest management and the need to take other ESs into account,

229 development of DSSs are going in this direction. Besides timber and biomass, this study includes

230 biodiversity and four important ES categories that forest ecosystems provide and that forest

231 management may affect in different ways:

232 1) Biodiversity conservation (hereafter "biodiversity" and considered an ES) - based on three

233 habitat proxies for biodiversity at both stand and landscape scales, i.e., tree species

234 composition, forest structures (e.g. large trees, dead wood, etc.), and spatial-temporal

235 disturbance patterns. The specifics will of course vary (to some extent) between case study

236 areas and the wildlife supported will depend on context and the proximity of species pools.

237 2) Carbon sequestration (including carbon storage in the forest) - based on three main carbon

238 pools, i.e., above and below ground biomass, deadwood, and harvested wood products. 
3) Other regulatory services (hereafter "regulatory services" and not including carbon sequestration) - other regulatory services apart from carbon sequestration, including forest attributes (e.g. tree species composition, stand age, etc.) that influence the risk and impact of catastrophic events at both stand and landscape scales, i.e., wildfire, windstorms, pests, snowstorms and droughts.

4) Recreational and aesthetic value - based on visual forest characteristics at both stand and landscape scales, conceptualized through the concepts of stewardship, naturalness/disturbances, complexity, visual scale, historicity/imageability, and ephemera (i.e., landscape changes that are the outcome of seasonal variation (Ode et al. 2008)).

250 Variables that are needed as output from the DSSs for evaluating the effects on ESs under different

251 scenarios and FMMs are listed in Table 3. They were identified as part of this study by experts on these

252 ESs, who developed standards for how each of these ESs should be modeled using a typical forest DSS, 253 based on the available input data and specifying the resulting outputs (Nieuwenhuis and Nordström 254 2017).

[INSERT TABLE 3 AROUND HERE]

\section{Global climate change and market scenarios applied in the assessment}

259 Global scenarios to be used as a background for landscape level scenarios produced by forest DSSs

260 should provide trends in the demand and prices for various timber assortments at least at the country

261 level based on developments in trade and on global markets. To include effects of climate change on 
262 forest growth and development, the global scenarios should also provide information on climate effects, 263 namely temperature and precipitation.

264 The global scenarios considered in this study provide this information with 10-year intervals until 2100 265 and reflect three alternative development pathways for this period:

266 1) Current development - Taking into account the EU policies until 2020 that are in the current

3) Global development toward the climate targets - Climate policies are assumed to be taken into action globally, but their effects are mostly seen in the latter half of the century.

274 These three scenarios were prepared using the global land use model GLOBIOM/G4M (Havlík et al.

275 2011; Kindermann et al. 2013) and were based on the policy targets for the European Union combined 276 with the Representative Concentration Pathways (RCP) - Shared Socioeconomic reference Pathways

277 (SSP) framework developed for the IPCC (IPCC 2013, 2014a, b; van Vuuren et al. 2011, 2014). The

278 framework consisted of two sets of independent scenarios in a matrix that allowed for various

279 combinations of scenarios: the four RCPs corresponding to different levels of radiative forcing, and the

280 SSPs that express the development of socioeconomic drivers. Since these are the most recent scenarios

281 produced by the IPCC based on substantial scientific input, they were the most appropriate scenarios

282 available for this kind of analysis, but any global scenarios providing similar information could be used.

283 The three global scenarios in this study are all based on the SSP2 "Middle of the road" scenario in 
combination with RCP4.5 (Current development), RCP8.5 (Rapid development of EU bioenergy sector)

285 and RCP2.6 (Global development toward the climate targets). The climate model used to produce these 286 scenarios was HadGEM2-ES.

\section{Specific DSS properties considered in the assessment}

\section{Timber assortments and prices}

289 Timber and timber assortments is the basic output for most forest DSSs, but since there may still be

290 differences, the DSSs are categorized into different levels of detail concerning the modeling. Timber

291 assortments are classified in two main categories, 'stemwood' and 'other biomass' (i.e., tops, branches

292 and stumps). For each category, the level of detail provided by each DSS is described using four levels of 293 increasing complexity:

294 1) harvested wood is given only in total volumes for each category (stemwood and other biomass),

4) in addition to level 3, transport costs should be included as well.

299 The capability to include and model changing timber prices and the effect on forest management is

300 needed as a link to global climate and market change scenarios that shows how prices for timber change

301 due to, e.g., market developments for bioenergy due to climate policies. For this project, the global

302 scenarios produced with the GLOBIOM/G4M model are downscaled to national level. These price trends

303 were expressed as average decadal mill gate prices for two assortment categories, sawlog and

304 pulpwood. In the DSSs, this price information (and linear interpolation) should be used in the

305 simulation/optimisation of the choice of FMMs over the planning horizon. Price changes should 
306 therefore be reflected in the harvest levels. The most important aspect of the prices is their trend, so

307 the global trend should be properly reflected when landscape level scenarios are produced for each case 308 study.

\section{Climate change}

310 The global scenarios described in the section on timber prices also include climate change trends for

311 each country, indicating overall temperature and precipitation changes over the period until 2100 for

312 each country. To fully incorporate climate change effects, the DSSs should be capable of modelling

313 climate change in terms of its impact on tree growth and tree mortality. As these are the fundamental

314 processes behind forest dynamics from tree to landscape level, such DSSs can also provide ESs provision

315 trends under changing climate. In the assessment, climate change trends that can be incorporated in the

316 DSSs are described and variables in the DSSs that are impacted by these trends and the data sources for

317 the models used in the DSSs to represent these impacts are identified.

\section{Owner behaviour}

319 The Forest Landscape Development Scenarios (FoLDS) framework (Hengeveld et al. 2017) has been

320 presented as an approach to model forest owner behaviour, and in this study the FoLDS framework will

321 be used as a baseline for the assessment of how owner behaviour is included in the DSSs.

323 In the FoLDS framework, different forest owner types (OTs) are defined along with their potential use of

324 different forest management models (FMMs). This can be described using a so-called OT-FMM matrix. In

325 this matrix, the proportions of the forest estate owned by different OTs are identified, and for each OT,

326 the proportions of their forests that are managed using different FMMs are quantified. In order to

327 reflect changing conditions over time, the values in this OT-FMM matrix should be dynamic, reflecting

328 changes in OT proportions and in the FMMs that each OT uses. For instance, forests may be inherited by 
329 city dwellers from farmers, resulting in different OT proportions, as well as changed management

330 objectives resulting in the use of different FMMs. At the same time, within (certain) OTs, the changing

331 market conditions (reflected by demand and prices) and the changes in climate will result in changes in

332 the (proportions of) FMMs used. Certain OT and their choice of FMMs may also be influenced by other

333 stakeholders. Existing FMMs are forest management models that are currently being used, while

334 alternative FMMs are management models that will be introduced in the future to deal with changing

335 market and climate conditions, and owner and stakeholder requirements. Existing OTs are categories of

336 forest owners grouped according to their management objectives and use of FMMs. New OTs may

337 develop over time based on changing market, socio-economic, environmental and climate conditions.

339 Thus, to incorporate the OT-FMM approach in a DSS, data on existing FMM proportions for existing OTs

340 and variables influencing OT behaviour (i.e., the selection and proportions of FMMs used) are needed. In

341 addition, alternative FMMs and new OTs and their behavior need to be defined based on sound

342 assumptions. For each decade (or other period), an OT-FMM matrix in which the proportions of existing

343 and alternative FMMs used by each existing and new OT can then be defined.

\section{$346 \quad$ Spatial specificity}

347 The level of spatial specificity in the DSS is relevant especially in the modeling of ESs but also affects

348 other aspects (e.g., the possibility to include transportation costs in the costs for harvesting). In this

349 study, spatial specificity in a DSS is considered to depend on the source of the spatial data used in the

350 DSS, the data format, and if forest stands, inventory plots or other basic forest information units are

351 used as a basis or if they are grouped into homogenous strata (based on stand, site and management

352 characteristics) and, if so, at what scale. The reason is that grouping will result in a partial loss of spatial 
353 specificity, as the location of each stand is lost in the strata. If no grouping takes place, the level of

354 spatial specificity is still affected by whether the adjacency of stands is known within the DSS and how

355 this information is used. 


\section{Results}

357 The results of the assessment of the DSSs are summarized for the ESs and for each property in the

358 following sections. Table 4 shows a classification of the nine DSSs according to their ability to quantify

359 the variables required for the ES provision assessment. A green cell indicates that the variable is part of

360 the DSS and that the ES is assessed within the DSS and a red cell indicates that the variable is not part of

361 the DSS. A yellow cell indicates that some of the analysis required to produce the outputs for the

362 variable in question can only be done outside of the DSS, though based on the DSS

363 simulation/optimisation outputs, i.e., by using models or software that are not part of the DSS. For

364 instance, frequently separate GIS software is needed for spatial analysis since several DSSs lack this

365 functionality. When a DSS does not include certain models, e.g., for dead wood, harvest residues or

366 below ground biomass, this also results in a yellow cell since separate models are then used to calculate

367 the variables based on output from simulation/optimization carried out in the DSS.

369 Ecosystem Services

370 Most of the DSSs include the standard forest inventory variables (Table 4); however, non-timber related

371 variables such as those associated with stand structure and dead wood are less often an integral part of

372 the DSSs and need to be quantified outside of the DSS, for instance in a stand-alone GIS, or are not part

373 of the DSS at all. In most DSSs, the definition of decision variables is based on harvest related options.

374 These options need to be considered in order to address concerns with both wood and non-wood goods

375 and services. Nevertheless, the outcome of the simulation or optimization depends in most cases on

376 timber related criteria (i.e., they are the decision variables), while other criteria are more often

377 addressed when analyzing the results of the simulation and optimization processes. This demonstrates

378 that most DSSs have their origin in traditional forest management, with environmental and social

379 elements added at a later stage. 


\section{Timber assortments and prices}

384 Concerning the timber assortment 'stemwood', most DSSs can output harvested wood volumes per 385 stemwood assortment (sawlogs, pulpwood and firewood). Furthermore, most DSS may include 386 harvesting costs. In some cases, the analysis is conducted considering stumpage prices and thus

387 harvesting and transportation costs are considered indirectly (e.g., SADfLOR). SILVA is the only DSS that 388 can include transportation costs (based on assumptions on distances). Kupolis, EFISCEN-space, Sibyla, 389 Heureka and ETÇAP can only include transportation costs in the forest up to the roadside.

390 Most DSSs use look-up tables to account for dynamic timber prices (Supplementary Table S1). In many

391 cases, the modeling would also be based on the assumption that rising timber prices would lead to at

392 least some increased management activity or even changes in FMMs for some OTs. A chain of effects 393 from changing prices to changing FMMs and changes in ESs provisioning levels seems to be expected for 394 most of the DSSs.

\section{Climate change}

397 All but three of the DSSs currently include climate models of some kind (Supplementary Table S2), which 398 allow for the modeling of climate change effects on growth rates, either on tree or stand level. In 399 Kupolis, SADfLOR and ETÇAP, which do not explicitly include climate models, climate change effects 400 could be included in a similar way by adjusting growth rates; the main problem in these cases is the lack 401 of data on climate change effects on growth. In some DSSs the climate change scenarios used to assess 
402 the impact on forest growth, and hence forest products supply, do not correspond to the global

403 scenarios used to derive timber price and demand. Therefore, supply and demand are not perfectly

404 balanced and may not be directly comparable in these cases.

\section{Owner behaviour}

407 All of the DSSs can somehow take owner behavior in terms of FMMs into account and make the OT-

408 FMM matrix dynamic over time in scenarios. The OT-FMM matrix describing the current situation is

409 based on multiple sources: information from stakeholders, expert knowledge, scientific studies, forest

410 statistics and inventory data (Supplementary Table S3). These will also be the basic sources for

411 formulation of OT-FMM matrices that describe the future state, but there is obviously a great challenge

412 in making predictions about future OTs and alternative FMMs.

\section{Spatial specificity}

415 The level of spatial specificity varies between the DSSs (Supplementary Table S4). Half of the DSSs use

416 stand-level data and the rest group stands into strata in the analysis, resulting in a loss of stand-level

417 spatial specificity in the assessment of the ESs. Most of the DSSs are spatial to the degree that the

418 locations of stands in the landscape are known, but only two of them (SADfLOR and ETÇAP) can handle

419 the more complex issue of adjacency, i.e., the relative location of stands in relation to each other. 


\section{Discussion}

424 This study is motivated by the need to provide policy makers as well as forest owners with decision

425 support on how various FMMs will affect the output of ESs and biodiversity, and how global drivers as

426 well as forest owner behavior on local level can influence future development. The capacity of a number

427 of forest DSSs to perform the kind of analyses needed is assessed based on their capabilities to model

428 the provisioning of ES under various FMMs and properties of the DSSs relevant to that. The discussion

429 focuses on how the DSSs cope with the modelling of timber and biomass, biodiversity, carbon

430 sequestration, regulatory services, recreational and aesthetic value and water. Certain properties of the

431 DSSs and lessons learned concerning methodological approaches are also discussed and needs for future

432 development of the DSSs are identified.

\section{Modelling of ecosystem services}

\section{Timber and biomass}

435 For most DSSs in this study, timber is clearly the ES which has been in focus when the DSS was

436 developed and all DSSs are very strong in the modelling of timber, both the standing stock and

437 harvested volumes. This is in line with previous research on forest DSSs (Vacik and Lexer 2014; Nobre et

438 al. 2016). The DSSs can output harvested volumes of stemwood and the basic assortments sawlog,

439 pulpwood and firewood. However, not all these DSSs can model output of residues that can be used for,

440 e.g., bioenergy, probably because this is not a traditional assortment in the area where those DSSs are

441 used. This may be a limiting factor when scenarios with alternative FMMs are created, but using

442 estimates based on results from DSSs applied in similar types of forest could be a solution to this

443 problem. 
444 An issue that required adjustment of the timber and biomass prices used in the modelling was that the

445 global scenarios considered in this study included prices for material delivered to the industry (i.e., mill

446 gate prices) while almost all DSSs only included harvesting and primary in-forest transport costs and not

447 secondary transport costs such as road haulage. This is because the systems are not designed to link

448 harvesting operations in individual stands with the particular industries that will process the timber and

449 biomass, while the prices in the global scenarios consider the industry relevant mill gate prices because

450 the underlying reasoning is based on economic partial equilibrium modelling. This means that the global

451 scenario prices will have to be adjusted in each DSS to reflect the average secondary timber and biomass

452 transport costs within the case study areas.

\section{Biodiversity}

454 As the necessary parameters for modelling population-level responses are generally limited to a small

455 number of forest species (Johansson et al. 2016), the landscape scale implications for biodiversity from

456 forest management alternatives are often projected using biodiversity proxies (Felton et al. 2017b). In

457 this assessment we evaluated three categories of biodiversity proxies: forest structure, tree species

458 composition, and spatial-temporal disturbance patterns, all with demonstrated relevance to the

459 maintenance of biodiversity in production forest stands (Felton et al. 2017a). In this regard most of the

460 DSSs assessed appear to provide at least minimal indicators of direct relevance to each of these three

461 broad categories of habitat-relevant proxies. With respect to tree species composition, for example, all

462 of the DSSs are capable of modeling relevant outcomes. Capturing changes in tree species composition

463 is vital as a particular tree species provides distinctive resources and habitats which may now be rare

464 due to recent and historic shifts in land-use in many regions of Europe (Lindbladh et al. 2014; Reitalu et

465 al. 2013; Wulf and Rujner 2011). These changes are frequently associated with population declines and

466 increased extinction risk for many forest species (Berg et al. 1994; Lindenmayer et al. 2006). 
There are however some limitations with respect to DSS capabilities. A subset of the DSSs assessed were

469 unable to project some forest structures, including the provision of dead wood of different sizes, and in

470 one case, the capacity to model large trees. Large trees may be vital to habitat provision in forest

471 ecosystems, due to the resources and environments created by their well-developed crowns, complex

472 bark features, stem hollows, and sap flows (Lindenmayer et al. 2012; Siitonen and Ranius 2015). The

473 presence of old and large trees is also directly relevant to the provision of coarse woody debris within

474 forest landscapes (Jonsson et al. 2006; Lindenmayer and Franklin 2002). Dead wood is also a critical

475 resource for a large number of species in forests, which may represent a quarter of all forest species in

476 some regions (Siitonen 2001; Stokland et al. 2003). The capacity to model dead wood is thus often an

477 important capacity of DSSs when modelling habitat availability in these regions. The inability to do so

478 generally resulted from a lack of available input data for dead wood amounts and categories within

479 different forest types at different stages of forest development, or a lack of model parameters for

480 projecting, for example, dead wood decomposition rates. Qualitative assessments and/or expert input

481 may be means of at least partially compensating for such limitations. Careful consideration of trade-offs

482 is however required. For instance, increased amount of woody debris may lead to significant increase of

483 wildfire hazard in some ecosystems, which may ultimately induce loss of habitat and biodiversity in case

484 of occurrence of severe wildfire.

486 We also note that there are limitations with regards to the extent to which spatially explicit

487 considerations can be analyzed by these DSSs. In the case of biodiversity conservation indicators, it is

488 crucial that DSSs may extend from stand to landscape scale and include spatial components, as pointed

489 out by previous studies (Filyushkina et al. 2016; Nobre et al. 2016). There are biodiversity components

490 that may only be assessed at the landscape level. This is especially the case with respect to adjacency

491 issues. The spatial configuration of habitat availability and the proximity of source populations are of 
492 direct relevance to understanding population dynamics and emergent patterns in forest biodiversity

493 (Fahrig 2003). Additional complexities and concerns may be raised regarding the ability of DSSs to

494 capture the wide variation in resultant habitat availability that arises due to everything from ownership

495 differences in silvicultural interventions to fine scale differences in site conditions. More specifically, the

496 complexities and uncertainties involved in projecting the interactions of climate change, abiotic and

497 biotic disturbance regimes, and forest dynamics, highlight the need for caution when interpreting DSS

498 projections of future habitat availability. Despite these limitations, we believe that in general, current

499 DSS, in combination with qualitative assessments and expert opinion, should provide output of

500 sufficient resolution to distinguish FMMs in terms of their habitat provisioning capabilities.

\section{Carbon sequestration}

502 The variables listed in table 4 are useful for characterizing carbon stocks and for estimating carbon stock

503 changes or carbon gains and losses. These issues can be addressed, in a harmonized manner, by using

504 well developed conversion factors for standing volume (stocks) or volume increment (carbon gains) in

505 the case of above and below ground biomass (IPCC 2006). In the case of deadwood, carbon fluxes can be

506 estimated using inflows of carbon from harvest residues, the existing deadwood pool and published

507 decomposition factors (see Olajuyigbe et al. 2011; Yatskov et al. 2003). Carbon dynamics of harvested

508 wood products could be derived from timber assortments based on relationships between timber

509 assortments and semi-finished wood products (Donlan et al. 2013) and published half-lives using the

510 harvested wood products decay model (IPCC 2006). However, it must be recognized that the model

511 system boundary would not be limited to regional carbon stock changes given the large influence of

512 timber trade.

513 Alternative FMMs for carbon sequestration could be used to analyze effects of, e.g., plantation/clearfell

514 versus continuous cover forestry (Lundmark et al. 2016), rotation age and thinning intensity (Chikumbo 
515 and Starka 2012), low impact management versus extensive management (Vanderberg et al. 2011), fate

516 of harvested wood products and product substitution (Lundmark et al. 2016; Moore et al. 2012).

517 Different silvicultural practices and forest disturbance events influence forest and product carbon

518 storage over different time periods. The most common approach to account for this is to derive

519 estimates assuming steady-state to steady-state transitions by running model simulations for 3

520 rotations, typically $200-400$ years (e.g., Lundmark et al. 2016).

521 Carbon assessment only includes aboveground, belowground biomass, deadwood and harvested wood

522 product pools. However, carbon sequestration of European forest ecosystems is also influenced by the

523 balance of numerous other greenhouse gases such as $\mathrm{N}_{2} \mathrm{O}, \mathrm{CH}_{4}$ and $\mathrm{CO}$, particularly in relation to

524 fertilizers, forest fires and drainage of peatland soils (IPCC 2006). In countries where non- $\mathrm{CO}_{2}$ emissions

525 from forest may be large, such as resulting from the drainage of organic soils (Ireland, Sweden) or forest

526 fires (Portugal, Italy), additional efforts would be required to provide a more comprehensive greenhouse

527 gas footprint. Mineral soil carbon stock changes have not been included in the DSSs because of the large

528 uncertainty and difficulty in deriving these estimates. Current knowledge remains inconclusive on both

529 the magnitude and direction of carbon stock changes in mineral forest soils associated with forest type,

530 management and other disturbances, and cannot support broad generalizations (IPCC 2006). Emissions

531 from drained organic soils, on the other hand are well described and easily estimated if sufficient detail

532 on soil type and extent of drainage is known (IPCC 2006).

533 In many forest DSSs, land use change (i.e., afforestation or deforestation) can be included, but the

534 impact of such change on the carbon dynamics cannot be modeled, and yet such change will have a

535 profound influence on the regional carbon balance. This is confounded by the inability of most DSSs to

536 provide estimates of soil and dead organic matter stock changes, which may occur for years after a land 
537 use transition occurs. Estimation of soil stock changes, in particular, requires a high spatial resolution for 538 input data (i.e., soils types, etc.).

539 Perhaps the most influential process influencing forest mitigation potential is, and one not considered in 540 this context, the effect of energy and product substitution. Dearing Oliver et al. (2014) suggest that the 541 use of wood products for substitution could reduce global emission by $14 \%$ to $31 \%$. Lundmark et al.

542 (2016), suggest that product substitution had the greatest influence on overall mitigation capacity when 543 different FMMs were compared. Life cycle analysis of wood products provides a way of measuring the

$544 \mathrm{CO}_{2}$ savings that can be made by use of wood products and replacement of high $\mathrm{CO}_{2}$ emission potential 545 products such as energy, cement, etc. (Sathre and O'Connor 2010). The overall concept is avoidance of 546 emissions by replacement of processes or products using wood as a substitution (Sathre and O'Connor 547 2010). This is a complex problem and can only be introduced at the stand or regional scale using broad 548 generalizations for the fate of harvested products (see Lundmark et al. 2016). The only feasible solution 549 is to perform sensitivity or scenario analysis on different FMMs and use displacement factors (Sathre 550 and O'Connor 2010) to estimate emission savings due to product substitution above a BAU scenario. The 551 use of the three global scenarios presented for this study may provide a framework.

\section{Regulatory services}

553 Results evince that all DSSs in this study are able to quantify stand-level variables required to assess the

554 likelihood and damage associated to catastrophic events in the respective case study areas. This

555 information is an important basis for supporting regulatory ecosystem services at the landscape level,

556 but not entirely sufficient since spatial aspects are important to the regulatory services defined in this

557 study, i.e., wildfire, windstorms, pests, snowstorms and droughts. Most DSSs lack spatial analysis

558 components to assess how a catastrophic event may spread over a landscape. Moreover, the 559 comparability of results across case studies will depend on the definition of vulnerability classes 
560 according to the values of the stand-level variables. The literature underlines the local specificity of

561 models to assess the contribution of each FMM to the mitigation of impacts of catastrophic events. For

562 example, this was demonstrated by research that analyzed the correlation of inventory variables over

563 which forest managers have control and a) the likelihood of occurrence of wildfires (e.g., Botequim et al.

564 2013; Garcia-Gonzalo et al. 2012), b) the damage caused by wildfires (e.g., Gonzalez et al. 2007;

565 Marques et al. 2011) and c) the damage caused by windstorms (Zeng et al. 2010). For example, in the

566 Mediterranean region an increased frequency of extreme events such as fire and droughts is highly likely

567 as a result of climate change and will result in changes in ES output.

568 Future climate and forest management are likely to have a large influence on future forest disturbances

569 such as pest outbreaks, forest fires and windthrow effects. These disturbances are recognized as among

570 the most important components of forest greenhouse gas emissions and the effects may last for

571 hundreds of years after a disturbance event (Kurz et al. 2009; Moore et al. 2012; Vilen and Fernandes

572 2011). It would be important to include also likely emissions from disturbance under different FMMs in

573 scenario analysis. For example, low intervention management may result in limited regeneration and a

574 build-up of fuel sources (dead wood), which could increase the likelihood of fires, windthrow, etc.

575 Ideally, these risks must be included in the FMMs applied in the DSSs. A possible approach is the use of

576 mean disturbance intervals or disturbance probabilities for different forest management scenarios (see

577 Vanderberg et al. 2011). The complexity of modeling risks and effects of climate change and the need

578 for developing this further to provide relevant decision support for the development of adaptation and

579 mitigation strategies has been pointed out in previous reviews of forest DSS (Muys et al. 2010; Vacik and

580 Lexer 2014; Orazio et al. 2017).

\section{Recreational and aesthetic value}


582 Existing studies present experiences made with quantifying the recreational and aesthetic value in

583 forestry as well as in other fields, such as landscape research, and together they add up to an extensive

584 list of possible criteria and indicators that could be used to measure this value. The assessment of the

585 capabilities of the DSSs showed that variables related to other factors than traditional forest attributes

586 and silvicultural activities are difficult to implement. Considering that most forest DSSs have not been

587 specifically developed to include modeling of recreational and aesthetic values, the pragmatic approach

588 to provide output on this value was to focus on variables related to forest attributes (cf. Edwards et al.

589 2011). Focusing on these attributes provided a list as defined in Table 4.

590 All DSSs in this study have the capability to provide information on the output of recreational and

591 aesthetic value as they are defined in terms of these variables, but all the DSSs do not include all these

592 variables; what output can be delivered varies between DSSs. In order to still be able to compare

593 outcomes from different DSSs, a potential solution is to accept that the DSSs use different indicators for

594 recreational and aesthetic value and instead determine a total index score based on different indicators

595 for this ES and compare the outcomes for different FMMs for different countries. The forest data

596 commonly used as input for the DSSs might in some cases be complemented with data from other

597 sources. Especially variables related to spatial aspects are out of limits to many DSSs, e.g., spatial

598 relationships between different stands or between a forest stand and another feature in the landscape,

599 and may have to be omitted. However, as is the case for many of the DSSs, GIS analysis may be

600 performed outside the DSS to complement the DSS output.

601 Water

602 Most DSSs are not built with a focus on water related ESs. It is often difficult to relate ES indicators to

603 simple parameters at the stand level without additional modeling. For example, most DSSs do not

604 include evapotranspiration, soil water storage, annual erosion or nutrients uptake. To quantify the 
605 variation in these indicators additional modelling is required. Some DSSs do have built-in quantification

606 of ESs (such as soil erosion and sedimentation risk for Ireland), but others need to be integrated with

607 additional models. For most DSSs, outputs can be used to feed a simplified model able to evaluate some

608 water related ESs. For instance, though not explicitly included in the DSS, a rough estimation of water

609 yield is relatively simple to obtain from DSS outputs. For erosion control and chemical conditions some

610 of the parameters are available from the DSSs, such as the annual felling area and tree species

611 composition. For a better estimation, soil properties (e.g., water storage capacity and soil infiltration)

612 should be included as well as indicators such as local slopes or proximity to rivers, which is a spatial

613 variable. Flood protection and water flow maintenance are difficult to estimate since important

614 parameters are often missing, but inclusion of soil properties would be of help.

615 Spatial aspects are important for water related ESs on landscape level and the capabilities of the DSSs in

616 this respect could be improved. An important factor would be the inclusion of other land use than

617 forestry in the analysis, since water related ES provisioning is often similar even under different forest

618 management. However, an explicit spatial distribution of FMMs would also improve the output.

\section{Alternative forest management models}

621 Of the four properties identified as critical for the DSSs to project the output of ESs, the capability to

622 deal with changing timber and biomass prices over time, the capability to include climate change effects,

623 and the spatial specificity of the landscape scale analyses have been discussed above in connection to

624 the ESs. However, the capability to include alternative FMMs that may be used in the future needs some 625 further attention. 
626 The DSSs are mainly developed to address current issues and solve existing tasks. DSSs that are tailored

627 to stands of horizontally homogeneous cohorts have often been designed to describe competition and

628 growth on the stand level rather than on the individual tree level. Such models have successfully been

629 applied to silvicultural systems that focus on large even-aged stands. However, if other ESs beyond

630 wood production, climatic resilience and risk management are to be considered, a multi-species stand

631 structure with a continuous distribution of age classes may become relevant. Such alternative FMMs

632 usually go beyond the scope of operational DSS and there is a risk that alternative FMMs may be limited

633 by the existing functionality of DSSs and the current FMMs, which have also been highlighted by

634 previous reviews of forest DSS (Muys et al. 2010; Filyushkina 2016; Nobre et al. 2016). To use existing

635 empirical growth and yield models to include very different FMMs in scenarios can be problematic, e.g.,

636 if a DSS has been built and used mainly for even-aged forestry, models for tree growth and regeneration

637 will probably have to be adjusted or newly developed if the DSS is to be used to create scenarios that

638 include FMMs based on continuous cover forestry. Further development of the DSSs in this respect may

639 thus be essential if indeed the provision of ESs depends on mixed uneven-aged stands. To cover growth

640 and structure development of highly heterogeneous stands, model developers will need to describe the

641 effect of position-dependent thinning interventions on nearest-neighbour competition and growth.

642 While much of the theory implemented within modern DSSs will persist and contribute to future

643 development, many models may require an increase in their spatial discretization down to the individual

644 tree level. Nevertheless, the landscape ecology literature demonstrates that addressing the provision of

645 ESs other than timber may be achieved by targeting landscape structure and composition variables

646 (Borges and Hoganson 2000). It is landscape-scale process and form that provide the framework to

647 ecological functioning (Baker 1992). The relation between the forested landscape spatial structure and

648 its ecological characteristics was highlighted by several authors (e.g., Bradshaw 1992; Franklin and

649 Forman 1987; Naiman et al. 1993). Hunter (1990) further emphasized that biodiversity in a forested 
650 landscape would be best preserved in a land mosaic characterized by a diverse array of stands. The DSSs

651 that report spatial analysis functionalities may thus be used to generate alternative landscape-level

652 FMMs and assess their contribution to the provision of a wide range of ESs.

\section{Landscape scale decision support}

654 The DSSs included in this study originated from stand-level forest management planning models that

655 incorporate single tree or stand growth and yield models. As is known from landscape ecology,

656 addressing the provision of ESs other than timber requires the evaluation of landscape-level structures

657 and composition variables. This study has shown that the assessed DSSs have been developed further

658 and are now capable of dealing with the analysis of ESs at the landscape level, but only for the forest

659 component. Only a few forest DSSs are capable of landscape analysis that includes other land cover than

660 forest and other land use than forestry, as shown in a review of the 63 DSSs listed on the wiki produced

661 within FORSYS, the EU-COST Action FP0804 Forest Management Decision Support Systems (Packalen et

662 al. 2013). Ecosystem service and climate impact research, beyond the prediction of productivity and

663 species composition, needs to address the above and below ground interactions within and between

664 forests and with neighbouring landscape units. A widened spectrum of ecosystem services that result

665 from the interaction among different components of the landscape, such as forests, agricultural areas

666 and anthropogenic systems can then be considered. For example, models that use a detailed

667 physiological component (Gutsch et al. 2002) are particularly suitable to represent hydrological

668 processes including lateral fluxes. Coupling of hydrological and ecosystem models may enhance the

669 quality of landscape-related case studies and enables the capturing of feedback processes between the

670 forest and the hydrological system, such as groundwater recharge and nutrient and pollutant discharge

671 (Molina-Herrera et al. 2015). 
672 The study at hand underpins that all the DSSs presented can quantify essential stand properties for

673 assessing forest vulnerability due to catastrophic events, which forms the basis for defining an effective

674 regulatory ecosystem service framework at the landscape level. However, the lateral interaction of

675 landscape elements is particularly relevant in the case of catastrophic events, such as the spread of fire

676 across the landscape (Luo et al. 2014) or the protection of forest areas against storm damage as a result

677 of shelter provided by other forests on the windward side and by other topographical landscape

678 features. Seed dispersal is also an important long-term landscape-level process within the scope of

679 forest resilience after fires and wind throw (Wang et al. 2013). Therefore, quantifying disturbance

680 processes and preventative management approaches is a typical objective of landscape models (e.g.

681 Syphard et al. 2011).

682 The rapid increase of computational capacity within research and land-use management institutions will

683 promote the integration of all landscape components into the DSSs so that interactions between and

684 within all landscape elements can be incorporated in the ES assessments (e.g. Schumacher et al. 2004).

685 At the same time, the refinement of the forest representation within the DSSs will continue (e.g.

686 through the development of physiological single-tree growth models) and will facilitate a more accurate

687 and detailed assessment of the effects of climate change on the development and productivity of the

688 forest component of the landscape.

689

690 Conclusions

691 To sum up, all DSSs assessed may be used to estimate the impacts of both stand and landscape-level

692 FMMs on the provision of a range of ecosystem services over a typical temporal planning horizon (e.g.,

693 one and a half rotation in the case of even-aged structures). Results evince further that DSSs can be

694 used to assess how timber price trends may impact that provision over time. The inclusion of forest 
owner behavior as reflected by the adoption of specific FMMs seems to be also in the reach of all DSS.

696 Nevertheless, in some cases the DSSs need more data and models that may help to estimate the impacts

697 of climate change on biomass production and other ESs. In scenarios covering long time horizons it is

698 crucial to include modelling of climate change effects, since the outputs of most ESs are likely to change

699 due to a changing climate. In many DSSs, the spatial analysis functionality need to be further developed

700 for a more accurate assessment of the landscape level output of ESs from both current and alternative

701 FMMs. The capability to include alternative and truly innovative FMMs is also an issue for many of the

702 DSSs, e.g., FMMs driven by the production of other ESs than timber and biomass.

703 Even though the DSSs produce estimates of the same ESs using the same variables, different methods

704 are used in the modelling approaches. The question is if the methodologies used to estimate the ESs

705 have an impact on the outputs and, ultimately, if the outputs, in terms of ES estimates, are really

706 comparable (cf. Biber et al. 2015). However, insisting on uniform methodologies could result in a loss of

707 relevance of ES estimations at the local landscape scale. We hope that this study has taken a few steps

708 in the direction of making outputs of different DSSs comparable by assessing their capabilities to

709 estimate certain ESs in an integrated manner using a range of global scenarios.

\section{References}

711 Andrew ME, Wulder MA, Nelson TA, Coops NC (2015) Spatial data, analysis approaches, and information

712 needs for spatial ecosystem service assessments: a review. GISci \& Remote Sens 52(3): 344-373.

713 https://doi.org/10.1080/15481603.2015.1033809

714 Baker WL (1992) The landscape ecology of large disturbances in the design and management of nature

715 reserves. Landsc Ecol 7: 181-194. https://doi.org/10.1007/BF00133309

716 Baskent EZ, Keles S (2005) Spatial forest planning: A review. Ecol Model 188(2-4): 145-173.

717 https://doi.org/10.1016/j.ecolmodel.2005.01.059.

718 Başkent EZ, Keleş S, Kadığulları Al (2013) Challenges in developing and implementing a decision support

719 systems (ETÇAP) in forest management planning: a case study in Honaz and Ibradı, Turkey. Scand J For

720 Res 29(sup1): 121-131. https://doi.org/10.1080/02827581.2013.822543 
721 Berg A, Ehnström B, Gustafsson L, Hallingbäck T, Jonsell M, Weslien J (1994) Threatened plant, animal, 722 and fungus species in Swedish forests - Distribution and habitat associations. Conserv Biol 8(3): 718-731.

723 Biber P, Borges JG, Moshammer R, Barreiro S, Botequim B, Brodrechtová Y, Brukas V, Chirici G, Cordero-

724 Debets R, Corrigan E, Eriksson LO, Favero M, Galev E, Garcia-Gonzalo J, Hengeveld G, Kavaliauskas M,

725 Marchetti M, Marques S, Mozgeris G, Navrátil R, Nieuwenhuis M, Orazio C, Paligorov I, Pettenella D,

726 Sedmák R, Smreček R, Stanislovaitis A, Tomé M, Trubins R, Tuček J, Vizzarri M, Wallin I, Pretzsch H,

727 Sallnäs $O$ (2015) How sensitive are ecosystem services in european forest landscapes to silvicultural

728 treatment? For 6: 1666-1695. https://doi.org/10.3390/f6051666

729 Borges JG, Garcia-Gonzalo J, Bushenkov VA, McDill ME, Marques S, Oliveira MM (2014a) Addressing 730 multi-criteria forest management with Pareto Frontier methods: an application in Portugal. For Sci 60:

731 63-72. https://doi.org/10.5849/forsci.12-100

732 Borges JG, Hoganson HM (2000) Structuring a landscape by forestland classification and harvest 733 scheduling spatial constraints. For Ecol Manag 130: 269-275. https://doi.org/10.1016/S0378-

734 1127(99)00180-2

735 Borges JG, Marques S, Garcia-Gonzalo J, Rahman AU, Bushenkov VA, Sottomayor M, Carvalho PO, 736 Nordström E-M (2017) A multiple criteria approach for negotiating ecosystem services supply targets 737 and forest owners' programs. For Sci 63: 49-61. https://doi.org/10.5849/FS-2016-035

738 Borges JG, Nordström E-M, Garcia-Gonzalo J, Hujala T, Trasobares A (2014b) Computer-based tools for 739 supporting forest management: the experience and the expertise world-wide. Department of Forest 740 Resource Management, Swedish University of Agricultural Sciences (SLU), Umeå.

741 Botequim B, Garcia-Gonzalo J, Marques S, Ricardo A, Borges JG, Tomé M, Oliveira M (2013) Developing 742 wildfire risk probability models for Eucalyptus globulus stands in Portugal. iForest 6:217-227.

743 https://doi.org/10.3832/ifor0821-006

744 Botequim B, Zubizarreta-Gerendiain A, Garcia-Gonzalo J, Silva A, Marques S, Fernandes P, Pereira J, 745 Tomé $M$ (2015) A model of shrub biomass accumulation as a tool to support management of Portuguese 746 forests. iForest 8: 114-125. https://doi.org/10.3832/ifor0931-008

747 Bradshaw FJ (1992) Quantifying edge effect and patch size for multiple-use silviculture: a discussion 748 paper. For Ecol Manag 48: 249-264. https://doi.org/10.1016/0378-1127(92)90148-3

749 de Bruin JO, Hoogstra-Klein MA, Mohren GMJ, Arts BJM (2015) Complexity of forest management:

750 exploring perceptions of Dutch forest managers. For 6 (9): 3237-3255.

751 https://doi.org/10.3390/f6093237

752 de Bruin JO, Kok K, Hoogstra-Klein MA (2017) Exploring the potential of combining participative 753 backcasting and exploratory scenarios for robust strategies: Insights from the Dutch forest sector. For

754 Policy Econ 85: 269-282. https://doi.org/10.1016/j.forpol.2017.06.007 
Bugalho MN, Caldeira MC, Pereira JS, Aronson JA, Pausas J (2011) Mediterranean cork oak savannas require human use to sustain biodiversity and ecosystem services. Front Ecol Environ 9(5): 278-286. https://doi.org/10.1890/100084

Bugalho MN, Dias FS, Briñas B, Cerdeira JO (2016) Using the high conservation value forest concept and Pareto optimization to identify areas maximizing biodiversity and ecosystem services in cork oak landscapes. Agrofor Syst 90: 35-44. https://doi.org/10.1007/s10457-015-9814-x

761 Canton A, Pettenella D (2010) Family forest owners' motivations in forest management activities: a case 762 study in Recoaro Terme municipality (north-east Italy). Forest@ 7: 44-57.

763 https://doi.org/10.3832/efor0618-007

764 Chikumbo O, Starka ST (2012) Maintaining an optimal flow of forest products under a carbon market: 765 Approximating a Pareto set of optimal silvicultural regimes for Eucalyptus fastigata. Open J For 2(3):

766 138-149. https://doi.org/10.4236/ojf.2012.23017

767 Clerkx A, Hengeveld G, Schelhaas M, Helmink A (2016) Boseigendom in Twente en Salland: resultaten 768 van een enquête onder kleine boseigenaren in Twente en Salland. Alterra-rapport 2731. Alterra-

769 Wageningen University and Research, Wageningen.

770 Corrigan E, Nieuwenhuis M (2017) Using goal-programming to model the effect of stakeholder

771 determined policy and industry changes on the future management of and ecosystem services provision

772 by Ireland's Western Peatland forests. Sustain 9(1): 11. https://doi.org/10.3390/su9010011

773 Dearing Oliver C, Nassar NT, Lippke BR, McCartet JB (2014) Carbon, fossil fuel, and biodiversity 774 mitigation with wood and forests. J Sustain For 33(3): 248-275.

775 https://doi.org/10.1080/10549811.2013.839386

776 Donlan J, Black K, Hendrick E, O'Driscoll E, Byrne KA (2013) Future change in carbon in harvested wood products from Irish forests established prior to 1990. Carbon Manag 4(4): 377-386.

778 https://doi.org/10.4155/cmt.13.37

779 Dudley N (ed) (2008) Guidelines for applying protected area management categories, including Stolton 780 S, Shadie P, Dudley N (2013) IUCN WCPA best practice guidance on recognising protected areas and 781 assigning management categories and governance types. Best Practice Protected Area Guidelines Series 782 No. 21, IUCN, Gland.

783 Edwards D, Jensen FS, Marzano M, Mason B, Pizzirani S, Schelhaas M-J (2011) A theoretical framework 784 to assess the impacts of forest management on the recreational value of European forests. Ecol Indic 785 11(1): 81-89. https://doi.org/10.1016/j.ecolind.2009.06.006

786 Eggers J, Holmström H, Lämås T, Lind T, Öhman K (2015) Accounting for a diverse forest ownership 787 structure in projections of forest sustainability indicators. For 6: 4001-4033.

788 https://doi.org/10.3390/f6114001 
Eggers J, Lämås T, Lind T, Öhman K (2014) Factors influencing the choice of management strategy among small-scale private forest owners in Sweden. For 5: 1695-1716. https://doi.org/10.3390/f5071695

791 Eigenbrod F, Armsworth P, Anderson B, Heinemeyer A, Gillings S, Roy D, Thomas C, Gaston K (2010) The 792 impact of proxy-based methods on mapping the distribution of ecosystem services. J Appl Ecol 47: 377793 385. https://doi.org/10.1111/j.1365-2664.2010.01777.x

794 Fabrika M, Ďurský J (2005) Algorithms and software solution of thinning models for SIBYLA growth 795 simulator. J For Sci 51(10):431-445.

796 Fabrika M, Pretzsch H (2013) Forest ecosystem analysis and modelling. Technical University in Zvolen, 797 Zvolen.

Fahrig L (2003) Effects of habitat fragmentation on biodiversity. Annu Rev Ecol Evol Syst 34: 487-515. https://doi.org/10.1146/annurev.ecolsys.34.011802.132419

800 Felton A, Ranius T, Roberge J-M, Öhman K, Lämås T, Hynynen J, Juutinen A, Mönkkönen M, Nilsson U, 801 Lundmark T (2017a) Projecting biodiversity and wood production in future forest landscapes: 15 key 802 modeling considerations. J Environ Manag 197: 404-414.

803 https://doi.org/10.1016/j.jenvman.2017.04.001

804 Felton A, Sonesson J, Nilsson U, Lämås T, Lundmark T, Nordin A, Ranius T, Roberge J-M (2017b) Varying 805 rotation lengths in northern production forests: Implications for habitats provided by retention and 806 production trees. Ambio 46(3):324-334. https://doi.org/10.1007/s13280-017-0909-7

807 Filyushkina A, Strange N, Löf M, Ezebilo EE, Boman M (2016) Non-market forest ecosystem services and 808 decision support in Nordic countries. Scand J For Res 31(1): 99-110.

809 https://doi.org/10.1080/02827581.2015.1079643

810 Franklin JF, Forman RT (1987) Creating landscape patterns by forest cutting: ecological consequences 811 and principles. Landsc Ecol 1: 5-18. https://doi.org/10.1007/BF02275261

812 Garcia-Gonzalo J, Zubizarreta-Gerendiain A, Ricardo A, Marques S, Botequim B, Borges JG, Oliveira MM, 813 Tomé M, Pereira JMC (2012) Modelling wildfire risk in pure and mixed forest stands in Portugal.

814 Allgemeine Forst und Jagdzeitung (AFJZ) - German Journal of Forest Research 183 (11/12): 238-248

815 González JR, Trasobares A, Palahí M, Pukkala T (2007) Predicting tree survival in burned forests in 816 Catalonia (North-East Spain) for strategic forest planning. Ann For Sci 64: 733-742.

817 https://doi.org/10.1051/forest:2007053

818 Grêt-Regamey A, Sirén E, Brunner SH, Weibel B (2016) Review of decision support tools to 819 operationalize the ecosystem services concept. Ecosyst Serv 26: 306-315.

820 https://doi.org/10.1016/j.ecoser.2016.10.012 
821 Gutsch M, Lasch-Born P, Suckow F, and Reyer CPO (2015) Modeling of two different water uptake approaches for mono-and mixed-species forest stands. Forests 6(6): 2125-2147.

823 https://doi:10.3390/f6062125. Havlík P, Schneider UA, Schmid E, Böttcher H, Fritz S, Skalský R, Aoki K, Cara SD, Kindermann G, Kraxner

826 F, Leduc S, McCallum I, Mosnier A, Sauer T, Obersteiner M (2011) Global land-use implications of first 827 and second generation biofuel targets. Energ Policy 39(10):5690-5702.

828 https://doi.org/10.1016/j.enpol.2010.03.030

829 Hengeveld GM, Didion M, Clerkx S, Elkin C, Nabuurs G-J, Schelhaas M-J (2015) The landscape-level effect 830 of individual-owner adaptation to climate change in Dutch forests. Reg Environ Change 15(8): 1515-

831 1529. https://doi.org/10.1007/s10113-014-0718-5

832 Hengeveld G, Schüll E, Trubins R, Sallnäs O (2017) Forest Landscape Development Scenarios (FoLDS) - A 833 framework for integrating forest models, owners' behaviour and socio-economic developments. For

834 Policy Econ 85: 245-255. https://doi.org/10.1016/j.forpol.2017.03.007

835 Hoogstra-Klein MA (2016) Exploring the financial rationales of Dutch forest holdings and their relation 836 with financial results. Eur J For Res 135(6): 1025-1036. https://doi.org/10.1007/s10342-016-0991-6

837 Hoogstra-Klein MA, Brukas V, Wallin I (2017) Multiple-use forestry as a boundary object: From a shared 838 ideal to multiple realities. Land Use Policy 69: 247-258.

839 https://doi.org/10.1016/j.landusepol.2017.08.029

840 Hoogstra-Klein M, Burger M (2013) Rational versus adaptive forest management planning: exploratory 841 research on the strategic planning practices of Dutch forest management organizations. Eur J For Res 842132 (5-6): 707-716. https://doi.org/10.1007/s10342-013-0707-0

843 Hunter ML (1990) Wildlife, forests and forestry. Principles of managing forests for biological diversity.

844 Prentice-Hall, New Jersey.

845 IPCC (2006) 2006 IPCC guidelines for national greenhouse gas inventories, prepared by the national 846 greenhouse gas inventories programme. Institute for Global Environmental Strategies, Hayama.

847 IPCC (2013) Climate change 2013: The physical science basis. Contribution of working group I to the fifth 848 assessment report of the Intergovernmental Panel on Climate Change. Cambridge University Press, 849 Cambridge and New York.

850 IPCC (2014a) Climate change 2014: Impacts, adaptation, and vulnerability. Part A: Global and sectoral 851 aspects. Contribution of working group II to the fifth assessment report of the Intergovernmental Panel 852 on Climate Change. Cambridge University Press, Cambridge and New York.

853 IPCC (2014b) Climate change 2014: Mitigation of climate change. Contribution of working group III to 854 the fifth assessment report of the Intergovernmental Panel on Climate Change. Cambridge University 855 Press, Cambridge and New York. 
Johansson V, Felton A, Ranius T (2016) Long-term landscape scale effects of bioenergy extraction on dead wood-dependent species. For Ecol Manag 371: 103-113.

858 https://doi.org/10.1016/j.foreco.2015.10.046

859 Jonsson M, Ranius T, Ekvall H, Bostedt G, Dahlberg A, Ehnström B, Nordén B, Stokland JN (2006) Cost860 effectiveness of silvicultural measures to increase substrate availability for red-listed wood-living 861 organisms in Norway spruce forests. Biol Conserv 127(4): 443-462.

862 https://doi.org/10.1016/j.biocon.2005.09.004

863 Kareiva P, Tallis H, Ricketts T, Daily G, Polasky S (eds) (2011) Natural capital. Theory and practice of 864 mapping ecosystem services. Oxford University Press, Oxford.

865 Kent B, Bare BB, Field RC, Bradley GA (1991) Natural resource land management planning using large866 scale linear programs: The USDA Forest Service experience with FORPLAN. Oper Res 39(1): 13-27.

867 https://doi.org/10.1287/opre.39.1.13

868 Kindermann GE, Schörghuber S, Linkosalo T, Sanchez A, Rammer W, Seidl R, Lexer MJ (2013) Potential 869 stocks and increments of woody biomass in the European Union under different management and 870 climate scenarios. Carbon Balance Manag 8(1): 2. https://doi.org/10.1186/1750-0680-8-2

871 Kindler E (2016) A comparison of the concepts: Ecosystem services and forest functions to improve 872 interdisciplinary exchange. For Policy Econ 67: 52-59. http://dx.doi.org/10.1016/j.forpol.2016.03.011

873 Kuliešis A, Kasperavičius A, Kulbokas G, Brukas V, Petrauskas E, Mozgeris G (2017) Lithuania. In: Barreiro

874 S, Schelhaas M, McRoberts R, Kändler G (eds) Forest inventory-based projection systems for wood and 875 biomass availability. Managing Forest Ecosystems, vol 29. Springer, Cham, pp 223-239.

876 https://doi.org/10.1007/978-3-319-56201-8_19

877 Kurz WA, Dymond CC, White TM, Stinson G, Shaw CH, Rampley GJ, Smyth C, Simpson BN, Neilson ET, 878 Trofymow JA, Metsaranta J, Apps MJ (2009) CBM-CFS3: a model of carbon-dynamics in forestry and 879 land-use change implementing IPCC standards. Ecol Model 220(4): 480-504.

880 https://doi.org/10.1016/j.ecolmodel.2008.10.018

881 Li X, He HS, Wu Z, Liang Y, Schneiderman JE (2013) Comparing Effects of Climate Warming, Fire, and 882 Timber Harvesting on a Boreal Forest Landscape in Northeastern China. PLoS ONE, 8(4), e59747.

883 https://doi.org/10.1371/journal.pone.0059747

884 Lindbladh M, Axelsson A-L, Hultberg T, Brunet J, Felton A (2014) From broadleaves to spruce - the 885 borealization of southern Sweden. Scand J For Res 29(7): 686-696.

886 https://doi.org/10.1080/02827581.2014.960893

887 Lindenmayer BD, Franklin JF (2002) Conserving forest biodiversity: A comprehensive multiscaled 888 approach. Island Press, Washington. 
889 Lindenmayer DB, Franklin JF, Fischer J (2006) General management principles and a checklist of

890 strategies to guide forest biodiversity conservation. Biol Conserv 131(3): 433-445.

891 https://doi.org/10.1016/j.biocon.2006.02.019

892 Lindenmayer DB, Laurance WF, Franklin JF (2012) Global decline in large old trees. Sci 338(6112): 1305-

893 1306. https://doi.org/10.1126/science.1231070

894 Lundmark T, Bergh J, Nordin A, Fahlvik N, Poudel BC (2016) Comparison of carbon balances between

895 continuous-cover and clear-cut forestry in Sweden. Ambio 45(Suppl. 2): S203-S213.

896 https://doi.org/10.1007/s13280-015-0756-3

897 Luo X, He HS, Liang Y, Wang WJ, Wu Z, Fraser JS (2014). Spatial simulation of the effect of fire and

898 harvest on aboveground tree biomass in boreal forests of Northeast China. Landscape Ecology, 29(7),

899 1187-1200. https://doi.org/10.1007/s10980-014-0051-x

900 Marques S, Garcia-Gonzalo J, Borges JG, Botequim B, Oliveira MM, Tomé J, Tomé M (2011) Developing

901 post-fire Eucalyptus globulus Labill stand damage and tree mortality models for enhanced forest

902 planning in Portugal. Silv Fenn 45(1): 69-83

903 Millennium Ecosystem Assessment (2005) Ecosystems and human well-being: Synthesis. Island Press,

904 Washington D.C.

905 Molina-Herrera S, Haas E, Grote R, Kiese R, Klatt S, Kraus D, Kampffmeyer T, Friedrich R, Andreae H, 906 Loubet B, Ammann C, Horváth L, Larsen K, Gruening C, Frumau A, and Butterbach-Bahl K (2017)

907 Importance of soil NO emissions for the total atmospheric NO x budget of Saxony, Germany. Atmos

908 Environ 152: 61-76. doi:10.1016/j.atmosenv.2016.12.022

909 Montesarchio M, Mercogliano P, Manzi MP, Buccignani E (2012) A sensitivity study with the RCM

910 COSMO CLM over the north and center Italy. CMCC Research Papers Issue RP0143.

911 http://dx.doi.org/10.2139/ssrn.2195479

912 Moore PT, DeRose RJ, Long JN, van Miegroet H (2012) Using silviculture to influence carbon

913 sequestration in Southern Appalachian spruce-fir forests. For 3(2): 300-316.

914 http://dx.doi.org/10.3390/\$3020300

915 Mozgeris G, Brukas V, Stanislovaitis A, Kavaliauskas M, Palicinas M (2016) Owner mapping for forest

916 scenario modelling - A Lithuanian case study. For Policy Econ 85: 235-244.

917 http://dx.doi.org/10.1016/j.forpol.2016.02.002

918 Mozzato D, Gatto P (2016) Determinants, attitudes and willingness of private forest owners to produce 919 goods and services: A review of the international literature. Forest@ 13(1): 18-30.

920 https://doi.org/10.3832/efor1751-013 
921 Muys B, Hynynen J, Palahi M, Lexer MJ, Fabrika M, Pretzsch H, Gillet F, Briceño E, Nabuurs G-J, Kint V 922 (2010) Simulation tools for decision support to adaptive forest management in Europe. For Syst 19: 86-

923 99. https://doi.org/10.5424/fs/201019S-9310

924 Naiman RJ, Decamps H, Pollock M (1993) The role of riparian corridors in maintaining regional

925 biodiversity. Ecol Appl 3: 209-212. https://doi.org/10.2307/1941822

926 Nieuwenhuis M, Nordström E-M (2017) Milestone 9 - Quality standard to be met by the upgraded DSSs.

927 ALTERFOR Milestone report. https://www.alterfor-

928 project.eu/files/alterfor/download/Deliverables/ALTERFOR\%20MS9\%20Quality\%20standard\%20upgrad 929 up\%20DSS.PDF. Accessed 16 November 2017.

930 Nobre S, Eriksson Ljusk O, Trubins R (2016) The use of decision support systems in forest management:

931 Analysis of FORSYS Country Reports. For 7(3): 72. https://doi.org/10.3390/f7030072

932 Ode Å, Tveit MS, Fry G (2008) Capturing landscape visual character using indicators: touching base with

933 landscape aesthetic theory. Landscape Research, 33(1), 89-117. https://doi:

934 10.1080/01426390701773854

935 Olajuyigbe SO, Tobin B, Gardiner P, Nieuwenhuis M (2011) Stocks and decay dynamics of above- and 936 belowground coarse woody debris in managed Sitka spruce forests in Ireland. For Ecol Manag 262(6):

937 1109-1118. https://doi.org/10.1016/j.foreco.2011.06.010

938 Orazio C, Cordero Montoya R, Égolini M, Borges JG, Garcia-Gonzalo J, Barreiro S, Botequim B, Marques S,

939 Sedmák R, Smrĕcek R, Brodrechtová Y, Brukas V, Chirici G, Marchetti M, Moshammer R, Biber P, 940 Corrigan E, Eriksson LO, Favero M, Galev E, Hengeveld GM, Kavaliauskas M, Mozgeris G, Navráti R, 941 Nieuwenhuis M, Paligorov I, Pettenella D, Stanislovaitis A, Tomé M, Trubins R, Tǔcek J, Vizzarri M, Wallin 942 I, Pretzsch H, Sallnäs O (2017) Decision support tools and strategies to simulate forest landscape 943 evolutions integrating forest owner behaviour: A review from the case studies of the European project, 944 INTEGRAL. Sustainability 9(4): 599. https://doi.org/10.3390/su9040599

945 Packalen T, Marques AF, Rasinmäki J, Rosset C, Mounir F, Rodriguez LCE, Nobre SR (2013) A brief 946 overview of forest management decision support systems (FMDSS) listed in the FORSYS wiki. For Syst 947 22(2): 263-269. http://dx.doi.org/10.5424/fs/2013222-03192

948 Packalen T, Sallnäs O, Sirkiä S, Korhonen KT, Salminen O, Vidal C, Robert N, Colin A, Belouard T, 949 Schadauer K, Berger A, Rego F, Louro G, Camia A, Räty M, San-Miguel-Ayanz J (2014) The European 950 forestry dynamics model (EFDM). JRC Scientific and Policy Reports, Publications Office of the European 951 Union, Luxembourg.

952 Pretzsch H (2009) Forest dynamics, growth, and yield. A review, analysis of the present state, and 953 perspective. Springer, Berlin and Heidelberg. https://doi.org/10.1007/978-3-540-88307-4_1

954 Pretzsch H, Biber P, Ďurský J (2002) The single tree-based stand simulator SILVA: construction, 955 application and evaluation. For Ecol Manag 162:3-21. https://doi.org/10.1016/S0378-1127(02)00047-6 
Rauscher HM (1999) Ecosystem management decision support for federal forests in the United States: A review. For Ecol Manag 114(2-3): 173-197. https://doi.org/10.1016/S0378-1127(98)00350-8

958 Ray D, Xenakis G, Tene A, Black K (2009) Developing a site classification system to assess the impact of 959 climate change on species selection in Ireland. Irish For 66 (1\&2): 101-122.

960 Reitalu T, Seppä H, Sugita S, Kangur M, Koff T, Avel E, Kihno K, Vassiljev J, Renssen H, Hammarlund D 961 (2013) Long-term drivers of forest composition in a boreonemoral region: the relative importance of 962 climate and human impact. J Biogeogr 40: 1524-1534. https://doi.org/10.1111/jbi.12092

963 Reynolds KM (2005) Integrated decision support for sustainable forest management in the United 964 States: Fact or fiction? Comput Electron Agric 49(1): 6-23.

965 https://doi.org/10.1016/j.compag.2005.02.002

966 Reynolds KM, Rodriguez S, Bevans K (2003) User guide for the Ecosystem Management Decision Support 967 System, version 3.0. Environmental Systems Research Institute, Redlands.

968 Reynolds KM, Twery MJ, Lexer MJ, Vacik H, Ray D, Shao G, Borges JG (2008) Decision support systems in 969 natural resource management. In: Burstein F, Holsapple C (eds) Handbook on decision support systems. 970 International Handbooks on Information Systems Series, Handbook on Decision Support System 2. 971 Springer, Berlin and Heidelberg, pp. 499-534.

972 Rinaldi F, Jonsson R, Sallnäs O, Trubins R (2015) Behavioral modelling in a decision support system. For 973 6(2): 311-327. https://doi.org/10.3390/f6020311

974 Sathre R, O'Connor J (2010) Meta-analysis of greenhouse gas displacement factors of wood product 975 substitution. Environ Sci Policy 13: 104-114. https://doi.org/10.1016/j.envsci.2009.12.005

976 Schelhaas MJ, Clerkx APPM, Daamen WP, Oldenburger JF, Velema G, Schnitger P, Schoonderwoerd H, 977 Kramer H (2014) Zesde Nederlandse bosinventarisatie: methoden en basisresultaten. Alterra-

978 Wageningen University and Research, Wageningen.

979 Schumacher S, Bugmann H, Mladenoff DJ (2004) Improving the formulation of tree growth and 980 succession in a spatially explicit landscape model. Ecological Modelling 180(1): 175-194.

981 https://doi.org/10.1016/i.ecolmodel.2003.12.055

982 Seppelt R, Dormann CF, Eppink FV, Lautenbach S, Schmidt S (2011) A quantitative review of ecosystem 983 service studies: approaches, shortcomings and the road ahead. J Appl Ecol 48: 630-636.

984 https://doi.org/10.1111/j.1365-2664.2010.01952.x

985 Siitonen J (2001) Forest management, coarse woody debris and saproxylic organisms: Fennoscandian 986 boreal forests as an example. Ecol Bull 49: 11-41.

987 Siitonen J, Ranius T (2015) The importance of veteran trees for saproxylic insects. In: Kirby KJ, Watkins C 988 (eds) Europe's changing woods and forests: From wildwood to managed landscapes. CABI Publishing, 989 UK, pp. 140-153. 
990 Stokland JN, Eriksen R, Tomter SM, Korhonen K, Tomppo E, Rajaniemi S, Söderberg U, Toet H, Riis991 Nielson T (2003) Forest biodiversity indicators in the Nordic countries: status based on national forest 992 inventories. Nordic Council of Ministers, Copenhagen.

993 Syphard AD, Scheller RM, Ward BC, Spencer WD, Strittholt JR (2011) Simulating landscape-scale effects 994 of fuels treatments in the Sierra Nevada, California, USA. International Journal of Wildland Fire, 20(3), 995 364-383. https://doi.org/10.1071/WF09125

996 Twery MJ, Knopp PD, Thomasma SA, Rauscher HM, Nute DE, Potter WD, Maier F, Wang J, Dass M, 997 Uchiyama $\mathrm{H}$, Glende A, Hoffman RE (2005) NED-2: A decision support system for integrated forest 998 ecosystem management. Comput Electron Agric 49(1): 24-43.

999 https://doi.org/10.1016/j.compag.2005.03.001

1000 Twery MJ, Rauscher HM, Bennett DJ, Thomasma SA, Stout SL, Palmer JF, Hoffman RE, DeCalesta DS, 1001 Gustafson E, Cleveland H, Grove JM, Nute D, Kim G, Kollasch RP (2000) NED-1: integrated analyses for 1002 forest stewardship decisions. Comput Electro Agric 27(1-3): 167-193. https://doi.org/10.1016/S01681003 1699(00)00107-1

1004 United Nations (1992) Non-legally binding authoritative statement of principles for a global consensus 1005 on the management, conservation and sustainable development of all types of forests. United Nations, 1006 New York.

1007 Vacik H, Lexer MJ (2014) Past, current and future drivers for the development of decision support 1008 systems in forest management. Scand J For Res 29: 2-19.

1009 https://doi.org/10.1080/02827581.2013.830768

1010 Vanderberg MR, Boston K, Bailey J (2011) Maximizing carbon storage in Appalachians: Method for 1011 considering the risk if disturbance events. Proceedings of the 17th Central Hardwood Forest Conference 1012 GTR-NRS-P-78. https://www.nrs.fs.fed.us/pubs/gtr/gtr-p-78papers/15vanderbergp78.pdf. Accessed 23 1013 November 2017.

1014 Vilén T, Fernandes PM (2011) Forest fires in Mediterranean countries: $\mathrm{CO}_{2}$ emissions and mitigation 1015 possibilities through prescribed burning. Environ Manag 48: 558-567. https://doi.org/10.1007/s002671016 011-9681-9

1017 van Vuuren DP, Edmonds J, Kainuma M, Riahi K, Thomson A, Hibbard K, Hurtt GC, Kram T, Krey V, 1018 Lamarque J-F, Masui T, Meinshausen M, Nakicenovic N, Smith S, Rose SK (2011) The representative 1019 concentration pathways: An overview. Clim Change 109(1): 5-31. https://doi.org/10.1007/s10584-011$1020 \quad 0148-z$

1021 van Vuuren D, Kriegler E, O’Neill B, Ebi K, Riahi K, Carter T, Edmonds J, Hallegatte S, Kram T, Mathur R, 1022 Winkler $\mathrm{H}$ (2014) A new scenario framework for climate change research: Scenario matrix architecture. 1023 Clim Change 122(3): 373-386. https://doi.org/10.1007/s10584-013-0906-1 
1024 Wang WJ, He HS, Spetich M, Shifley SR, Thompson III FR, Larsen DR, Yang J (2013) A large-scale forest 1025 landscape model incorporating multi-scale processes and utilizing forest inventory data. Ecosphere, 4(9), 1026 art106. https://doi.org/10.1890/ES13-00040.1

1027 Winter S (2012) Forest naturalness assessment as a component of biodiversity monitoring and 1028 conservation management. Forestry 85(2): 293-304. https://doi.org/10.1093/forestry/cps004

1029 Wolff S, Schulp C, Verburg P (2015) Mapping ecosystem services demand: A review of current research 1030 and future perspectives. Ecol Indic 55: 159-171. https://doi.org/10.1016/j.ecolind.2015.03.016

1031 Wulf M, Rujner H (2011) A GIS-based method for the reconstruction of the late eighteenth century 1032 forest vegetation in the Prignitz region (NE Germany). Landsc Ecol 26: 153-168.

1033 https://doi.org/10.1007/s10980-010-9555-1

1034 Yatskov M, Harmon ME, Krankina ON (2003) A chronosequence of wood decomposition in the boreal 1035 forests of Russia. Can J For Res 33(7): 1211-1226. https://doi.org/10.1139/x03-033

1036 Zeng H, García-Gonzalo J, Peltola H, Kellomäki S (2010) The effects of forest structure on the risk of wind 1037 damage at a landscape level in a boreal forest ecosystem. Ann For Sci 67(1): 111.

1038 https://doi.org/10.1051/forest/2009090

1039 
Table 1. Description of the DSSs considered in the assessment

\begin{tabular}{|c|c|c|c|c|}
\hline $\begin{array}{l}\text { System } \\
\text { name }\end{array}$ & Country & $\begin{array}{l}\text { Forestry } \\
\text { dynamics model } \\
\text { type }^{a}\end{array}$ & $\begin{array}{l}\text { Modeling } \\
\text { approach }^{\text {b }}\end{array}$ & Further information on DSS \\
\hline SILVA & $\begin{array}{l}\text { Germany } \\
\text { (GER) }\end{array}$ & $\begin{array}{l}\text { stand dynamics } \\
\text { model }\end{array}$ & simulation & Pretzsch 2009; Pretzsch et al. 2002 \\
\hline $\begin{array}{l}\text { Remsoft } \\
\text { Woodstock }\end{array}$ & Ireland (IRL) & $\begin{array}{l}\text { tightly coupled } \\
\text { integrated stand } \\
\text { and forestry } \\
\text { dynamics model }\end{array}$ & optimisation & Corrigan and Nieuwenhuis 2017 \\
\hline $\begin{array}{l}\text { InVEST and } \\
\text { VALE }\end{array}$ & Italy (IT) & $\begin{array}{l}\text { not forestry } \\
\text { dynamics models } \\
\text { (GIS and Excel } \\
\text { based models) }\end{array}$ & simulation & $\begin{array}{l}\text { InVEST: Kareiva et al. } 2011 \\
\text { http://data.naturalcapitalproject.org/nightly-build/invest-users-guide/html/ }\end{array}$ \\
\hline Kupolis & $\begin{array}{l}\text { Lithuania } \\
\text { (LIT) }\end{array}$ & $\begin{array}{l}\text { tightly coupled } \\
\text { integrated stand } \\
\text { and forestry } \\
\text { dynamics model }\end{array}$ & simulation & Kuliešis et al. 2017 \\
\hline $\begin{array}{l}\text { EFISCEN- } \\
\text { space }\end{array}$ & $\begin{array}{l}\text { Netherlands } \\
\text { (NL) }\end{array}$ & $\begin{array}{l}\text { matrix model of } \\
\text { forestry dynamics } \\
\text { with a spatial } \\
\text { extension }\end{array}$ & simulation & Schelhaas et al. manuscript in prep. \\
\hline SADfLOR & $\begin{array}{l}\text { Portugal } \\
\text { (POR) }\end{array}$ & $\begin{array}{l}\text { tightly coupled } \\
\text { integrated stand } \\
\text { and forestry } \\
\text { dynamics model }\end{array}$ & $\begin{array}{l}\text { simulation, } \\
\text { optimisation }\end{array}$ & $\begin{array}{l}\text { http://www.isa.ulisboa.pt/cef/forchange/fctools/en/SimflorPlatform/ StandSimulators } \\
\text { http://www.forestdss.org/wiki/index.php ?title=SADfLOR web-based }\end{array}$ \\
\hline Sibyla & $\begin{array}{l}\text { Slovakia } \\
\text { (SVK) }\end{array}$ & $\begin{array}{l}\text { stand dynamics } \\
\text { model }\end{array}$ & simulation & $\begin{array}{l}\text { Fabrika and Pretzsch } 2013 \\
\text { http://sibyla.tuzvo.sk/index.html }\end{array}$ \\
\hline $\begin{array}{l}\text { Heureka } \\
\text { and } \\
\text { HoldSim }\end{array}$ & $\begin{array}{l}\text { Sweden } \\
\text { (SWE) }\end{array}$ & $\begin{array}{l}\text { tightly coupled } \\
\text { integrated stand } \\
\text { and forestry }\end{array}$ & $\begin{array}{l}\text { simulation, } \\
\text { optimisation }\end{array}$ & $\begin{array}{l}\text { Stand simulator: Heureka: http://www.slu.se/en/collaborative-centres-and-projects/forest-sustainability- } \\
\text { analysis/en-heureka/ } \\
\text { Landscape simulator built on AIMMS: https://aimms.com/ }\end{array}$ \\
\hline
\end{tabular}




\begin{tabular}{|l|l|l|l|l|}
\hline & & dynamics model & \\
\hline ETÇAP & Turkey (TUR) & $\begin{array}{l}\text { loosely coupled } \\
\text { integrated stand } \\
\text { and forestry } \\
\text { dynamics model }\end{array}$ & $\begin{array}{l}\text { simulation, } \\
\text { optimization }\end{array}$ & Başkent et al. 2013 \\
\hline
\end{tabular}

a Corresponds to the categorization of forestry dynamics models in Packalen et al. (2014).

${ }^{b}$ Corresponds to the methods groups categorization of DSSs in Nobre et al. (2016), though the category 'MCDA' was not considered here. 
Table 2: Details of the case study areas (CSA)

\begin{tabular}{|c|c|c|c|c|c|}
\hline $\begin{array}{l}\text { CSA name } \\
\text { (Country) }\end{array}$ & $\begin{array}{l}\text { Area, } 1000 \text { ha } \\
\text { (\% forest) }\end{array}$ & \begin{tabular}{|l|} 
Forest ownership (\%) \\
\end{tabular} & Main stakeholders & Main ES & DSS(s) used \\
\hline $\begin{array}{l}\text { Augsburg Western } \\
\text { Forests (GER) }\end{array}$ & $150(33)$ & $\begin{array}{l}50 \text { Private } \\
50 \text { Public }\end{array}$ & $\begin{array}{l}\mathrm{PFO}^{\mathrm{a}}, \mathrm{ENGOs}^{\mathrm{b}} \text {, forest service forest industry, general } \\
\text { public (stable ownership structure for decades) }\end{array}$ & $\begin{array}{l}\text { Timber, Biodiversity, } \\
\text { Recreation, Water, Soil } \\
\text { protection }\end{array}$ & SILVA \\
\hline $\begin{array}{c}\text { Lieberose - } \\
\text { Schlaubetal (GER) }\end{array}$ & $90(37)$ & $\begin{array}{l}44 \text { Private } \\
56 \text { Public }\end{array}$ & $\begin{array}{l}\text { PFO (their share steadily increasing), forest service } \\
\text { ENGOs, forest industry, general public }\end{array}$ & $\begin{array}{l}\text { Timber, Biodiversity, } \\
\text { Recreation, Soil protection }\end{array}$ & SILVA \\
\hline $\begin{array}{c}\text { Barony of } \\
\text { Moycullen (IRL) }\end{array}$ & $81(16)$ & $\begin{array}{l}22 \text { Private } \\
78 \text { Public }\end{array}$ & $\begin{array}{l}\text { Forest service, advisory services, PFO, ENGO, } \\
\text { industries, public, fisheries, investment bodies }\end{array}$ & $\begin{array}{l}\text { Timber, Biodiversity } \\
\text { Water, Recreation }\end{array}$ & $\begin{array}{c}\text { Remsoft } \\
\text { Woodstock }\end{array}$ \\
\hline Telšiai (LIT) & $254(34)$ & $\begin{array}{l}63 \text { Private } \\
37 \text { Public }\end{array}$ & $\begin{array}{l}\text { Institute of Forest Management Planning, state forest } \\
\text { managers, PFO, ENGO, regional park }\end{array}$ & $\begin{array}{l}\text { Timber, Biodiversity } \\
\text { Water, Recreation }\end{array}$ & Kupolis \\
\hline $\begin{array}{l}\text { The Netherlands } \\
\text { (NL) }\end{array}$ & $3,734(11)$ & $\begin{array}{l}52 \text { private } \\
48 \text { public }\end{array}$ & $\begin{array}{c}\text { National and regional government, } F^{c} A^{c} \text {, state } \\
\text { forestry, National Trust, non-industrial PFO \& general } \\
\text { public }\end{array}$ & $\begin{array}{c}\text { Timber, recreation, } \\
\text { biodiversity }\end{array}$ & EFISCEN-space \\
\hline Sousa Valley (POR) & $15(10)$ & $\begin{array}{l}100 \text { Private } \\
\text { 0 Public }\end{array}$ & $\begin{array}{l}\text { FOA, forest owner federation, forest industry, forest } \\
\text { service, local municipality, other NGO }\end{array}$ & Timber, Recreation & SADfLOR \\
\hline $\begin{array}{l}\text { Kronoberg county } \\
\text { (SWE) }\end{array}$ & $847(77)$ & $\begin{array}{l}83 \text { Private } \\
17 \text { Public }\end{array}$ & $\begin{array}{l}\text { FOA, ENGO, forest industry, Swedish Forest Agency, } \\
\text { public }\end{array}$ & $\begin{array}{l}\text { Timber, Biodiversity, } \\
\text { Water, Recreation }\end{array}$ & $\begin{array}{l}\text { Heureka } \\
\text { HoldSim }\end{array}$ \\
\hline Gölcük (TUR) & $83(58)$ & $\begin{array}{l}1 \text { Private } \\
99 \text { Public }\end{array}$ & $\begin{array}{c}\text { General Directorate of Forestry, NGOs, forest } \\
\text { industry, public }\end{array}$ & $\begin{array}{l}\text { Timber, Biodiversity, Water, } \\
\text { Recreation, Non-wood } \\
\text { Forest Products }\end{array}$ & ETÇAP \\
\hline
\end{tabular}

a private forest owners

${ }^{b}$ Environmental non-governmental organization(s)

c Forest owners' association 
Table 3. List of variables required as output from the DSSs on stand and/or landscape level for quantification of the ESs (marked in the table as S=stand level and $\mathrm{L}=$ landscape level)

\begin{tabular}{|c|c|c|c|c|c|c|c|c|}
\hline Variable & Unit & Comment & $\begin{array}{c}\text { Timber and } \\
\text { biomass }\end{array}$ & $\begin{array}{l}\text { Recreational } \\
\text { and aesthetic } \\
\text { value }\end{array}$ & $\begin{array}{l}\text { Regulatory } \\
\text { services }\end{array}$ & $\begin{array}{c}\text { Carbon } \\
\text { sequestration }\end{array}$ & Water & Biodiversity \\
\hline Afforestation & age of forest cover (per period) & Concerns afforestation of non-forest land, not regeneration after final felling & & $\mathrm{S}, \mathrm{L}$ & & & & \\
\hline Age & year (per period) & Mean age & & $\mathrm{S}, \mathrm{L}$ & $\mathrm{s}$ & & S,L & \\
\hline Basal area & $\mathrm{m}^{2} /$ ha (per period) & & & $S, L$ & $\mathrm{~s}$ & & & \\
\hline Below ground biomass & kt C/ha (per period) & & & & & L & & \\
\hline Dead wood, logs & $\mathrm{m}^{3} / \mathrm{ha}$ and $\mathrm{kt} \mathrm{C} / \mathrm{ha}$ (per period) & Per species & & $\mathrm{S}, \mathrm{L}$ & & $\mathrm{L}$ & & $\mathrm{S}, \mathrm{L}$ \\
\hline Dead wood, stumps and roots & kt C/ha (per period) & & & & & $\mathrm{L}$ & & \\
\hline Density/openness & stems/ha (per period) & & & $\mathrm{S}, \mathrm{L}$ & $\mathrm{s}$ & & & $\mathrm{S}, \mathrm{L}$ \\
\hline $\begin{array}{l}\text { Fertilization (nitrogen and/or } \\
\text { phosphorus) }\end{array}$ & $\mathrm{kg} / \mathrm{ha}$ and area fertilized (per period) & & & & & & S,L & \\
\hline Final felling area & ha (per period) & $\begin{array}{l}\text { For uneven-aged forests: size of contiguous harvested areas. For } \\
\text { shelterwood: two figures regarding harvested area / time period are given }\end{array}$ & & $\mathrm{S}, \mathrm{L}$ & & & S,L & $\mathrm{L}$ \\
\hline Forest edges & $\mathrm{m} / \mathrm{ha}$ (per period) & Length of forest edge relative to the landscape area & & $\mathrm{L}$ & & & & \\
\hline Forest stand size & ha (per period) & Area of individual stands & & $\mathrm{L}$ & & & & \\
\hline Forest stand types & $\begin{array}{l}\text { no. of different stand types in the } \\
\text { landscape (per period) }\end{array}$ & Definitions of forest stand types may differ & & $\mathrm{L}$ & & & & \\
\hline Harvested wood, total & $\mathrm{m}^{3} /$ ha (per period) & & $\mathrm{S}, \mathrm{L}$ & & & $\mathrm{L}$ & S,L & s \\
\hline Large dead wood & stems/ha (per period) & $\begin{array}{l}\text { Per species, suggestion for size classes (diameter in } \mathrm{cm} \text { ): }>30 \mathrm{~cm},>40 \mathrm{~cm} \text {, } \\
>50 \mathrm{~cm},>60 \mathrm{~cm}\end{array}$ & D,L & & & 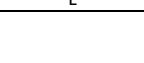 & O,L & $\frac{S, L}{L}$ \\
\hline Large trees & $\mathrm{m}^{3} /$ ha and stems/ha (per period) & $\begin{array}{l}\text { Per species, suggestion for size classes (diameter in } \mathrm{cm} \text { ): }>30 \mathrm{~cm},>40 \mathrm{~cm} \text {, } \\
>50 \mathrm{~cm},>60 \mathrm{~cm}\end{array}$ & & & & & & $\mathrm{~S}, \mathrm{~L}$ \\
\hline Naturalness & Hemeroby index (per period) & $\begin{array}{l}\text { The hemeroby index measures the deviation from the potential natural } \\
\text { vegetation caused by human activities (see Winter 2012). Gradients of } \\
\text { human influence are assessed on a scala from "naturall or non-disturbed } \\
\text { landscapes and habitats to totally disturbed or "artrificial" landscapes. In this } \\
\text { study the naturalness is assessed based on stand characteristics (varying } \\
\text { depending on region and forest type) on the following scale: } 0=\text { natural, } \\
\text { non-disturbed forest, } 0.33 \text { c close to natural, } 0.66 \text { semi-natural, } 1 \text { = } \\
\text { relatively far from natural (monoculture, plantations) }\end{array}$ & & $\mathrm{S}, \mathrm{L}$ & & & & \\
\hline Protected area & ha (per period) & Area as per IUCN category (Dudley 2008) & & & & & & $\mathrm{L}$ \\
\hline Residues harvested & $\begin{array}{l}\mathrm{m}^{3} / \mathrm{ha} \text { or } \mathrm{kg} / \mathrm{ha} \text {, and area where } \\
\text { residues are harvested (per period) }\end{array}$ & $\begin{array}{l}\text { In final felling (and thinning if possible/applicable, but these should be } \\
\text { separated) }\end{array}$ & $S, L$ & S, L & & $\mathrm{L}$ & & \\
\hline Spatial fragmentation & $\begin{array}{l}\text { index value per habitat/forest type (per } \\
\text { period) }\end{array}$ & $\begin{array}{l}\text { Spatial fragmentation refers to the composition (i.e. the amount of habitat) } \\
\text { and configuration (i.e.e, the size of habitat patches and the extent to which } \\
\text { they are aggregated or dispersed of the landscape) and can be described by } \\
\text { different landscape measures/indices, e.g., number and mean area of } \\
\text { patches, core area and shape index of patches (Baskent and Keles 2005). }\end{array}$ & & & $\mathrm{L}$ & & & $\mathrm{L}$ \\
\hline Standing volume & $\mathrm{m}^{3} / \mathrm{ha}$ and $\mathrm{kt} / \mathrm{ha}$ (per period) & & $\mathrm{S}, \mathrm{L}$ & & & $\mathrm{L}$ & $\mathrm{S}, \mathrm{L}$ & $\mathrm{s}$ \\
\hline Tree height & $\mathrm{m}$ (per period) & Dominant height & & & $\mathrm{s}$ & & & \\
\hline Tree size diversity & $\mathrm{m}^{3} /$ size class (per period) & $\begin{array}{l}\text { Suggestion for size classes (diameter in cm): 1-10, 11-20, 21-30, 31-40, 41- } \\
50,51-60,>61\end{array}$ & & $\mathrm{~s}$ & $\mathrm{~s}$ & & & $\mathrm{~S}, \mathrm{~L}$ \\
\hline Tree species composition & $\mathrm{m}^{3} /$ ha (per period) & Per species & & $\mathrm{S}, \mathrm{L}$ & $\mathrm{s}$ & & $\mathrm{S}, \mathrm{L}$ & $\mathrm{S}, \mathrm{L}$ \\
\hline Understory & $\mathrm{m}^{3} / \mathrm{ha}$ or no/yes (per period) & & & $\mathrm{S}, \mathrm{L}$ & $\mathrm{s}$ & & & \\
\hline $\begin{array}{l}\text { Volume harvested by } \\
\text { assortments (sawlogs and } \\
\text { pulpwood) }\end{array}$ & $\mathrm{m}^{3} / \mathrm{ha}$ and kt c/ha (per period) & & $S, L$ & & & $\mathrm{~L}$ & & \\
\hline
\end{tabular}


Table 4. Classification of the nine DSSs according to their ability to quantify the variables required for the ES provision assessment. A green cell indicates that the variable is part of the DSS and that the ES is assessed within the DSS; a yellow cell indicates that the variable is part of the DSS but that the ES is assessed outside of the DSS following the simulation/optimisation; and a red cell indicates that the variable is not part of the DSS. The DSSs included are (left to right, starting at the top row): SILVA (Germany), Remsoft Woodstock (Ireland), InVEST and VALE (Italy), Kupolis (Lithuania), EFISCENspace (Netherlands), SADfLOR (Portugal), Sibyla (Slovakia), Heureka (Sweden) and ETÇAP (Turkey)

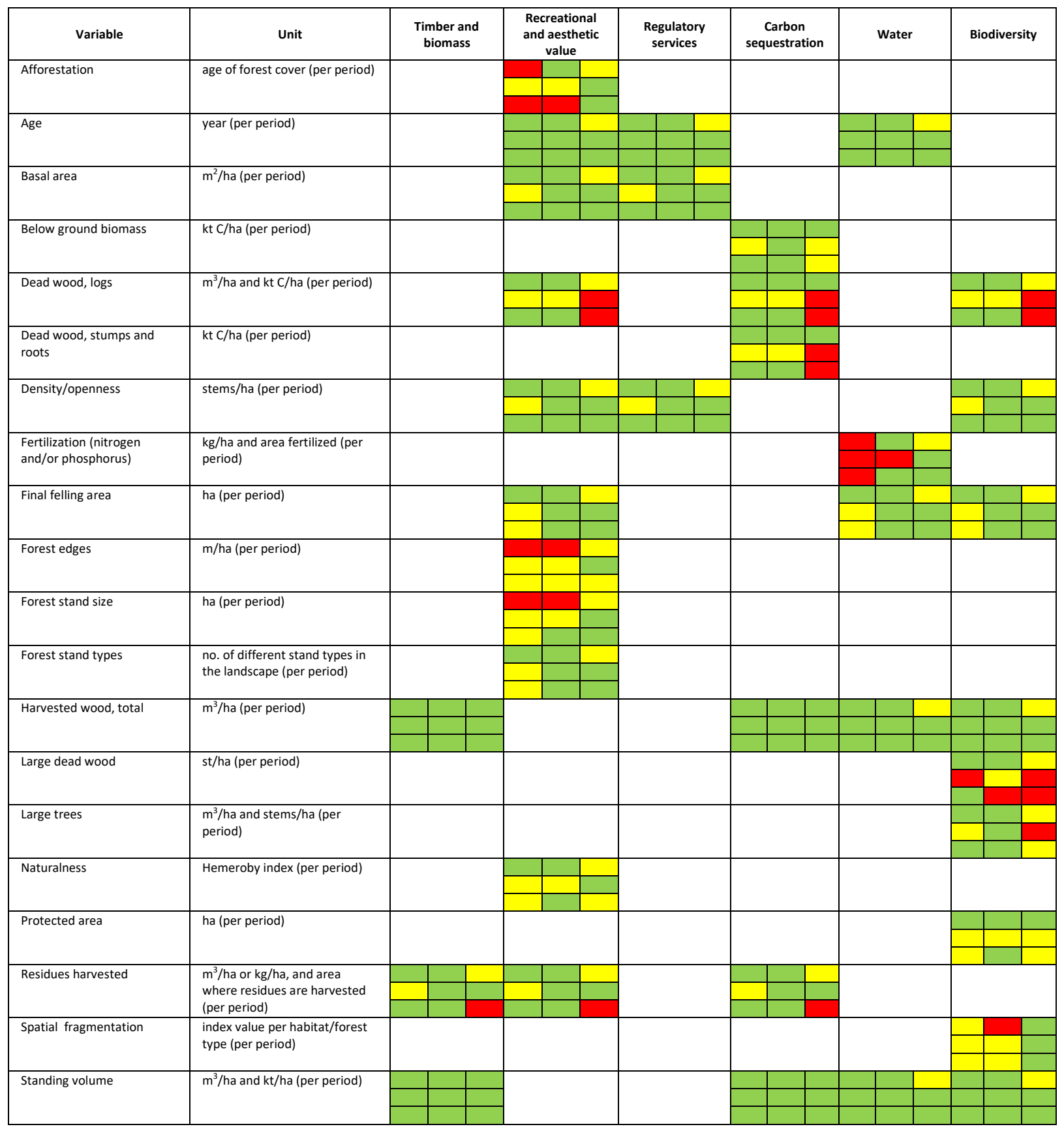




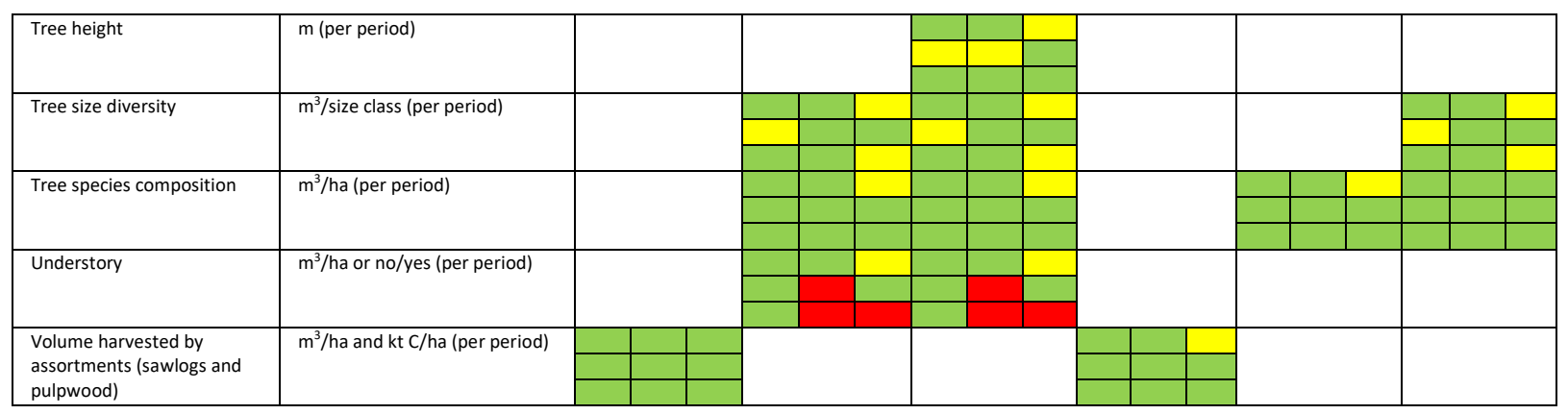




\section{Supplementary Material}

for

Forest decision support systems for analysis of ecosystem services provisioning at landscape scale under global climate and market change scenarios

Eva-Maria Nordström, Maarten Nieuwenhuis, Peter Biber, Emin Zeki Başkent, Kevin Black, Jose G. Borges, Miguel N. Bugalho, Giulia Corradini, Edwin Corrigan, Ljusk Ola Eriksson, Adam Felton, Nicklas Forsell, Geerten Hengeveld, Marjanke Hoogstra-Klein, Anu Korosuo, Matts Lindbladh, Isak Lodin, Anders Lundholm, Marco Marto, Mauro Masiero, Gintautas Mozgeris, Davide Pettenella, Werner Poschenrieder, Robert Sedmak, Jan Tucek and Davide Zoccatelli 
Supplementary Table S1. DSS information in relation to the use of dynamic timber prices as provided by the global scenarios

\begin{tabular}{|c|c|c|c|c|}
\hline $\begin{array}{l}\text { DSS } \\
\text { (Country) }\end{array}$ & $\begin{array}{l}\text { Ability to } \\
\text { include global } \\
\text { price trends } \\
\text { in DSS }\end{array}$ & Methodology used & $\begin{array}{l}\text { Assumptions on how OT } \\
\text { reacts to prices }\end{array}$ & $\begin{array}{l}\text { DSS outputs influenced } \\
\text { by changing prices }\end{array}$ \\
\hline $\begin{array}{l}\text { SILVA } \\
\text { (GER) }\end{array}$ & Yes & $\begin{array}{l}\text { Look-up table with } \\
\text { periodic assortment } \\
\text { prices }\end{array}$ & $\begin{array}{l}\text { Depending on OT, higher } \\
\text { prices may lead to the use } \\
\text { of FMMs that increase } \\
\text { harvesting. Reactions are } \\
\text { strong (very un-elastic) } \\
\text { for economically focused } \\
\text { OTs, and quite elastic for } \\
\text { OTs focused on other, } \\
\text { e.g., biodiversity-related } \\
\text { goals. }\end{array}$ & $\begin{array}{l}\text { Harvest volumes, FMM } \\
\text { selection by OTs, ES } \\
\text { provision levels. }\end{array}$ \\
\hline $\begin{array}{l}\text { Remsoft } \\
\text { Woodstock } \\
\text { (IRL) }\end{array}$ & Yes & $\begin{array}{l}\text { Look-up table with } \\
\text { periodic assortment } \\
\text { prices }\end{array}$ & $\begin{array}{l}\text { Depending on OT, higher } \\
\text { prices may lead to the use } \\
\text { of FMMs that increase } \\
\text { harvesting. }\end{array}$ & $\begin{array}{l}\text { Harvest volumes, NPV, } \\
\text { FMM selection by OTs, } \\
\text { ES provision levels }\end{array}$ \\
\hline $\begin{array}{l}\text { InVEST and } \\
\text { VALE } \\
\text { (IT) }\end{array}$ & Yes & $\begin{array}{l}\text { Look-up table with } \\
\text { periodic assortment } \\
\text { prices }\end{array}$ & $\begin{array}{l}\text { Higher prices may lead to } \\
\text { the use of FMMs that } \\
\text { increase harvesting, } \\
\text { though timber production } \\
\text { is not the main aim of } \\
\text { current FMMs. }\end{array}$ & $\begin{array}{l}\text { Harvest volumes, NPV } \\
\text { and other } \\
\text { financial/economic } \\
\text { profitability and risk } \\
\text { indicators, ES provision } \\
\text { levels }\end{array}$ \\
\hline $\begin{array}{l}\text { Kupolis } \\
\text { (LIT) }\end{array}$ & Yes & $\begin{array}{l}\text { Look-up table with } \\
\text { periodic timber prices }\end{array}$ & $\begin{array}{l}\text { Changing prices have no } \\
\text { influence on FO behavior } \\
\text { as existing FMMs are } \\
\text { based on legal and } \\
\text { ecological conditions of } \\
\text { the forests. }\end{array}$ & $\begin{array}{l}\text { Costs, incomes and } \\
\text { profits of forestry } \\
\text { activities. More detailed } \\
\text { outputs will be } \\
\text { generated outside DSS, } \\
\text { including NPV by FMM, } \\
\text { FOT, etc. }\end{array}$ \\
\hline $\begin{array}{l}\text { EFISCEN- } \\
\text { space } \\
(\mathrm{NL})\end{array}$ & Yes & $\begin{array}{l}\text { Look-up table with } \\
\text { periodic assortment } \\
\text { prices. }\end{array}$ & $\begin{array}{l}\text { Higher prices may lead to } \\
\text { the use of FMMs that } \\
\text { increase harvesting. }\end{array}$ & $\begin{array}{l}\text { FMM selection by OTs } \\
\text { and all outputs, } \\
\text { includingES provision } \\
\text { levels }\end{array}$ \\
\hline $\begin{array}{l}\text { SADfLOR } \\
\text { (POR) }\end{array}$ & Yes & $\begin{array}{l}\text { The increase/decrease } \\
\text { price rates of the } \\
\text { global scenarios are } \\
\text { used and applied to } \\
\text { initial local prices to } \\
\text { compute NPVs }\end{array}$ & No assumptions made. & $\begin{array}{l}\text { FMM selection by OTs } \\
\text { and all outputs, including } \\
\text { ES provision levels. }\end{array}$ \\
\hline $\begin{array}{l}\text { Sibyla } \\
\text { (SVK) }\end{array}$ & No & $\begin{array}{l}\text { Look-up table with } \\
\text { assortment prices, } \\
\text { constant over time. }\end{array}$ & $\begin{array}{l}\text { OTs are assumed to } \\
\text { expect current prices to } \\
\text { persist. }\end{array}$ & \\
\hline $\begin{array}{l}\text { Heureka } \\
\text { and } \\
\text { HoldSim } \\
\text { (SWE) }\end{array}$ & Yes & $\begin{array}{l}\text { Look-up table with } \\
\text { periodic assortment } \\
\text { prices. }\end{array}$ & $\begin{array}{l}\text { Depending on OT, higher } \\
\text { prices may lead to the use } \\
\text { of FMMs that increase } \\
\text { harvesting. }\end{array}$ & $\begin{array}{l}\text { FMM selection by OTs } \\
\text { and all outputs, including } \\
\text { ES provision levels. }\end{array}$ \\
\hline
\end{tabular}




\begin{tabular}{|l|c|l|l|l|}
\hline $\begin{array}{l}\text { ETÇAP } \\
\text { (TUR) }\end{array}$ & $\begin{array}{c}\text { To a certain } \\
\text { extent }\end{array}$ & $\begin{array}{l}\text { Current prices are } \\
\text { guided by interest } \\
\text { rate to reflect } \\
\text { periodical changes in } \\
\text { prices over time. }\end{array}$ & $\begin{array}{l}\text { Depending on OT, higher } \\
\text { prices may lead to the use } \\
\text { of FMMs that increase } \\
\text { harvesting. }\end{array}$ & $\begin{array}{l}\text { All outputs related to } \\
\text { prices. }\end{array}$ \\
\hline
\end{tabular}


Supplementary Table S2. DSS information in relation to the use of climate change data as provided by the global scenarios. Cited studies are listed in the References section of the article.

\begin{tabular}{|c|c|c|c|c|}
\hline $\begin{array}{l}\text { DSS } \\
\text { (Country) }\end{array}$ & $\begin{array}{l}\text { Climate } \\
\text { change } \\
\text { modelling } \\
\text { is part of } \\
\text { DSS }\end{array}$ & $\begin{array}{l}\text { Climate change data } \\
\text { source }\end{array}$ & $\begin{array}{l}\text { Variables/models } \\
\text { affected }\end{array}$ & Scientific basis and references \\
\hline $\begin{array}{l}\text { SILVA } \\
\text { (GER) }\end{array}$ & Yes & $\begin{array}{l}\text { HadGEM2-ES } \\
\text { projections }\end{array}$ & $\begin{array}{l}\text { Single tree growth } \\
\text { potential }\end{array}$ & Pretzsch 2009; Pretzsch et al. 2002 \\
\hline $\begin{array}{l}\text { Remsoft } \\
\text { Woodstock } \\
\text { (IRL) }\end{array}$ & Yes & $\begin{array}{l}\text { Met Eireann's C4I } \\
\text { projections of A2 and } \\
\text { B1 scenarios in IPCC } \\
\text { SRES }\end{array}$ & $\begin{array}{l}\text { Stand growth by } \\
\text { species, species } \\
\text { selection }\end{array}$ & ClimAdapt. Ray et al. 2009 \\
\hline $\begin{array}{l}\text { InVEST and } \\
\text { VALE } \\
\text { (IT) }\end{array}$ & Yes & $\begin{array}{l}\text { Based on CMCC's } \\
\text { regional elaborations } \\
\text { via COSMO-CLM } \\
\text { (radiation scenarios } \\
\text { RCP } 4.5 \text { and } 8.5 \text { ) }\end{array}$ & Stand growth & $\begin{array}{l}\text { http://www.cmcc.it/models/3d- } \\
\text { cmcc-fem-three-dimension-forest- } \\
\text { ecosystem-model } \\
\text { Montesarchio et al. } 2012\end{array}$ \\
\hline $\begin{array}{l}\text { Kupolis } \\
\text { (LIT) }\end{array}$ & $\mathrm{No}^{\mathrm{a}}$ & & & \\
\hline $\begin{array}{l}\text { EFISCEN- } \\
\text { space } \\
\text { (NL) }\end{array}$ & Yes & $\begin{array}{l}\text { Any SRES or RCP } \\
\text { scenario downscaled } \\
\text { to } 1 \mathrm{~km}^{2} \text { maps }\end{array}$ & $\begin{array}{l}\text { Stand growth by } \\
\text { species }\end{array}$ & $\begin{array}{l}\text { Schelhaas et al. manuscript in } \\
\text { prep. }\end{array}$ \\
\hline $\begin{array}{l}\text { SADfLOR } \\
\text { (POR) }\end{array}$ & In part & & $\begin{array}{l}\text { Stand growth. A } \\
\text { shrub biomass } \\
\text { model can estimate } \\
\text { the impact on fuel } \\
\text { accumulation. }\end{array}$ & Botequim et al. 2015 \\
\hline $\begin{array}{l}\text { Sibyla } \\
\text { (SVK) }\end{array}$ & Yes & $\begin{array}{l}\text { Any SRES and/or RCP } \\
\text { scenarios providing } \\
\text { the projections of } \\
\text { temperatures, } \\
\text { precipitations, } \\
\text { temperature } \\
\text { amplitudes, air } \\
\text { humidity, content of } \\
\text { NOx and SO2 in air } \\
\text { and length of } \\
\text { growing season. }\end{array}$ & $\begin{array}{l}\text { Tree growth } \\
\text { potential and } \\
\text { related increments }\end{array}$ & $\begin{array}{l}\text { Fabrika and Ďurský } 2005 \\
\text { Fabrika and Pretzsch } 2013\end{array}$ \\
\hline
\end{tabular}




\begin{tabular}{|c|c|c|c|c|}
\hline $\begin{array}{l}\text { Heureka } \\
\text { and } \\
\text { HoldSim } \\
\text { (SWE) }\end{array}$ & Yes & $\begin{array}{l}\text { MPI 4.5: Based on } \\
\text { Max Planck Institute } \\
\text { MPI-ESM model } \\
\text { using radiation } \\
\text { scenario RCP 4.5. } \\
\text { MPI 8.5: Based on } \\
\text { Max Planck Institute } \\
\text { MPI-ESM model } \\
\text { using radiation } \\
\text { scenario RCP 8.5. } \\
\text { ECHAMS_A1B: Based } \\
\text { on Max Planck } \\
\text { Institute climate } \\
\text { model ECHAM using } \\
\text { emission scenario } \\
\text { SRES A1B. }\end{array}$ & Stand growth & $\begin{array}{l}\text { An approximation model of } \\
\text { BIOMASS. The BIOMASS model is } \\
\text { documented in Bergh et al. 2003; } \\
1998\end{array}$ \\
\hline $\begin{array}{l}\text { ETÇAP } \\
\text { (TUR) }\end{array}$ & No & & & \\
\hline
\end{tabular}

${ }^{a}$ Kupolis does not currently model changing climatic conditions. However, growth functions and forest regeneration characteristics used for simulation may be adjusted by the user based on, e.g., expert judgement. 
Supplementary Table S3. DSS information in relation to the use of Owner Type (OT) and Forest Management Model (FMM). Cited studies are listed in the References section of the article.

\begin{tabular}{|c|c|c|c|}
\hline $\begin{array}{l}\text { DSS } \\
\text { (Country) }\end{array}$ & $\begin{array}{l}\text { a) What variables } \\
\text { /parameters determine the } \\
\text { distribution of forest area to } \\
\text { OTs? } \\
\text { b) What is the source of } \\
\text { data? }\end{array}$ & $\begin{array}{l}\text { a) What variables/parameters } \\
\text { determine the allocation of existing } \\
\text { FMMs to existing OTs? } \\
\text { b) What is the source of data? }\end{array}$ & $\begin{array}{l}\text { Source of data for } \\
\text { new OTs and for } \\
\text { alternative FMMs } \\
\text { and associated } \\
\text { proportions }\end{array}$ \\
\hline $\begin{array}{l}\text { SILVA } \\
\text { (GER) }\end{array}$ & $\begin{array}{l}\text { a) The distribution is assumed } \\
\text { to be constant based on } \\
\text { historical distribution which } \\
\text { has been stable. } \\
\text { b) Forest inventory data }\end{array}$ & $\begin{array}{l}\text { a) OTs' preferences concerning ESs, } \\
\text { wood prices, wood demand. } \\
\text { b) stakeholder feedback (especially } \\
\text { from EU projects INTEGRAL and } \\
\text { ALTERFOR), long-term experience from } \\
\text { collaboration with certain OTs }\end{array}$ & $\begin{array}{l}\text { Stakeholder } \\
\text { interviews and } \\
\text { from forest } \\
\text { consulting } \\
\text { experience }\end{array}$ \\
\hline $\begin{array}{l}\text { Remsoft } \\
\text { Woodstock } \\
\text { (IRL) }\end{array}$ & $\begin{array}{l}\text { a) Land use } \\
\text { b) GIS datasets from State } \\
\text { forestry board, Irish } \\
\text { Department of Agriculture } \\
\text { and Ireland's Forest Service }\end{array}$ & $\begin{array}{l}\text { a) Timber prices, species growth rates, } \\
\text { ES provision requirements } \\
\text { b) Expert knowledge, scientific } \\
\text { knowledge, INTEGRAL and ALTERFOR } \\
\text { stakeholder meetings }\end{array}$ & $\begin{array}{l}\text { Expert knowledge, } \\
\text { in Ireland and in } \\
\text { countries where } \\
\text { alternative FMMs } \\
\text { are already used }\end{array}$ \\
\hline $\begin{array}{l}\text { InVEST and } \\
\text { VALE } \\
\text { (IT) }\end{array}$ & $\begin{array}{l}\text { a \& b) Expert knowledge, } \\
\text { ALTERFOR stakeholder } \\
\text { meetings, existing literature } \\
\text { on forest owners' attitudes } \\
\text { towards FMM (Canton and } \\
\text { Pettenella 2010; Mozzato and } \\
\text { Gatto 2016) and other } \\
\text { relevant scientific and grey } \\
\text { literature }\end{array}$ & $\begin{array}{l}\text { a) Owner preferences, stakeholder } \\
\text { preferences, wood prices, legal } \\
\text { constraints (e.g., Natura } 2000 \text { sites) } \\
\text { b) Expert knowledge, ALTERFOR } \\
\text { stakeholder meetings, existing } \\
\text { literature on forest owners' attitudes } \\
\text { towards FMM }\end{array}$ & $\begin{array}{l}\text { Expert knowledge, } \\
\text { ALTERFOR } \\
\text { stakeholder } \\
\text { meetings }\end{array}$ \\
\hline $\begin{array}{l}\text { Kupolis } \\
\text { (LIT) }\end{array}$ & $\begin{array}{l}\text { a) Size of estate, total area of } \\
\text { forest owned, presence of } \\
\text { agricultural land-use in the } \\
\text { estate, environmental } \\
\text { restrictions on the estate, } \\
\text { characteristics of forest } \\
\text { stands } \\
\text { b) Real estate cadaster, forest } \\
\text { cadaster, expert knowledge }\end{array}$ & $\begin{array}{l}\text { a) A set of legal acts regulating the } \\
\text { forestry, characteristics of forest stands } \\
\text { b) Information available from state } \\
\text { forest cadaster, INTEGRAL stakeholder } \\
\text { meetings (Mozgeris et al. 2016) }\end{array}$ & $\begin{array}{l}\text { Expert knowledge, } \\
\text { stakeholder } \\
\text { contacts, } \\
\text { involvement of } \\
\text { non-academic } \\
\text { partner, and other } \\
\text { relevant research }\end{array}$ \\
\hline $\begin{array}{l}\text { EFISCEN- } \\
\text { space } \\
(\mathrm{NL})\end{array}$ & $\begin{array}{l}\text { a \& b) National forest } \\
\text { inventory (Schelhaas et al. } \\
\text { 2014) and local inventory } \\
\text { (Clerkx et al. 2016) }\end{array}$ & $\begin{array}{l}\text { a \& b) National forest inventory } \\
\text { (Schelhaas et al. 2014) and local } \\
\text { inventory (Clerkx et al. 2016), scientific } \\
\text { knowledge (Hoogstra-Klein 2016; } \\
\text { Hoogstra-Klein and Burger 2013), } \\
\text { INTEGRAL stakeholder meetings (de } \\
\text { Bruin et al. 2015; 2017), ALTERFOR } \\
\text { stakeholder meetings }\end{array}$ & $\begin{array}{l}\text { Stakeholder } \\
\text { contacts, relevant } \\
\text { research }\end{array}$ \\
\hline
\end{tabular}




\begin{tabular}{|l|l|l|l|}
\hline $\begin{array}{l}\text { SADFLOR } \\
\text { (POR) }\end{array}$ & $\begin{array}{l}\text { a) The distribution is based on } \\
\text { the history of the region and } \\
\text { the corresponding } \\
\text { socioeconomic and } \\
\text { demographic variables } \\
\text { b) INTEGRAL reports, } \\
\text { ALTERFOR stakeholder } \\
\text { meetings }\end{array}$ & $\begin{array}{l}\text { a) The history of the region and the } \\
\text { corresponding socioeconomic and } \\
\text { demographic variables. } \\
\text { b) INTEGRAL reports, ALTERFOR } \\
\text { stakeholder meetings }\end{array}$ & $\begin{array}{l}\text { ALTERFOR } \\
\text { stakeholder } \\
\text { meetings and } \\
\text { workshops }\end{array}$ \\
\hline $\begin{array}{l}\text { Sibyla } \\
\text { (SVK) }\end{array}$ & $\begin{array}{l}\text { a) Ownership rights, forestry } \\
\text { and nature conservation } \\
\text { legislation } \\
\text { b) Forest statistics, expert and } \\
\text { scientific knowledge, } \\
\text { INTEGRAL and ALTERFOR } \\
\text { stakeholder meetings and } \\
\text { interviews }\end{array}$ & $\begin{array}{l}\text { a) Ownership rights, forestry and nature } \\
\text { conservation legislation } \\
\text { b) Forest statistics, expert knowledge, } \\
\text { scientific knowledge, stakeholder } \\
\text { meetings }\end{array}$ & $\begin{array}{l}\text { Expert and } \\
\text { scientific } \\
\text { knowledge, } \\
\text { stakeholder } \\
\text { contacts, } \\
\text { ALTERFOR } \\
\text { stakeholder } \\
\text { meetings, } \\
\text { interviews }\end{array}$ \\
\hline $\begin{array}{l}\text { Heureka } \\
\text { and } \\
\text { HoldSim } \\
\text { (SWE) }\end{array}$ & $\begin{array}{l}\text { a) Size of property } \\
\text { b) Government register of } \\
\text { properties, map of stands in } \\
\text { GIS }\end{array}$ & $\begin{array}{l}\text { a) Preferences related to economic } \\
\text { interest, management tradition, } \\
\text { biodiversity interest, and degree of } \\
\text { involvement in management } \\
\text { b) Articles on forest owner strategies } \\
\text { (Eggers et al. 2014; 2015), interviews of } \\
\text { forest consultants from the forest } \\
\text { owners' association; forest statistics on } \\
\text { forest operations }\end{array}$ & $\begin{array}{l}\text { Stakeholder } \\
\text { contacts, stand- } \\
\text { level modelling } \\
\text { research }\end{array}$ \\
\hline $\begin{array}{l}\text { ETÇAP } \\
\text { (TUR) }\end{array}$ & $\begin{array}{l}\text { a) The distribution is assumed } \\
\text { to be static since almost all } \\
\text { forests are state owned by } \\
\text { legislation } \\
\text { b) Forest inventory data }\end{array}$ & $\begin{array}{l}\text { a) Management guidelines, species } \\
\text { type, site factors, timber prices, species } \\
\text { growth rates, ES provision } \\
\text { requirements } \\
\text { b) Knowledge of local foresters, } \\
\text { scientific knowledge, ALTERFOR } \\
\text { stakeholder meetings, national forest } \\
\text { inventory }\end{array}$ & $\begin{array}{l}\text { Major stakeholder } \\
\text { contacts, scientific } \\
\text { knowledge }\end{array}$ \\
\hline
\end{tabular}


Supplementary Table S4. DSS information in relation to the spatial data source, resolution, stratification and adjacency

\begin{tabular}{|c|c|c|c|c|c|}
\hline $\begin{array}{l}\text { DSS } \\
\text { (Country) }\end{array}$ & $\begin{array}{l}\text { Origin of spatial } \\
\text { data (i.e. } \\
\text { organisations } \\
\text { from which data } \\
\text { were obtained) }\end{array}$ & $\begin{array}{l}\text { Grouping of } \\
\text { stands into } \\
\text { strata? }\end{array}$ & $\begin{array}{l}\text { If grouping } \\
\text { is used, at } \\
\text { what scale? }\end{array}$ & $\begin{array}{l}\text { Is the location } \\
\text { of stands or } \\
\text { strata in the } \\
\text { landscape } \\
\text { known in the } \\
\text { DSS }\end{array}$ & $\begin{array}{l}\text { If no grouping, is } \\
\text { adjacency of stands } \\
\text { known in the DSS, and } \\
\text { how is this information } \\
\text { used? }\end{array}$ \\
\hline $\begin{array}{l}\text { SILVA } \\
\text { (GER) }\end{array}$ & $\begin{array}{l}\text { Raster inventory } \\
\text { plots from Federal } \\
\text { country forest } \\
\text { services and } \\
\text { Federal Republic } \\
\text { of Germany } \\
\text { (national forest } \\
\text { inventory data) }\end{array}$ & Yes & $\begin{array}{l}\text { Case study } \\
\text { area, by } \\
\text { stratum }\end{array}$ & $\begin{array}{l}\text { Yes, applies to } \\
\text { strata; } \\
\text { inventory data } \\
\text { resolution too } \\
\text { low on stand } \\
\text { scale }\end{array}$ & $\begin{array}{l}\text { No; spatial metrics } \\
\text { applied to set of } \\
\text { inventory plots used }\end{array}$ \\
\hline $\begin{array}{l}\text { Remsoft } \\
\text { Woodstock } \\
\text { (IRL) }\end{array}$ & $\begin{array}{l}\text { GIS datasets from } \\
\text { multiple sources }\end{array}$ & Yes $^{\mathrm{a}}$ & $\begin{array}{l}\text { Case study } \\
\text { area }^{\text {b }}\end{array}$ & Yes & $\mathrm{No}^{\mathrm{c}}$ \\
\hline $\begin{array}{l}\text { InVEST and } \\
\text { VALE } \\
\text { (IT) }\end{array}$ & $\begin{array}{l}\text { GIS datasets from } \\
\text { multiple sources }\end{array}$ & $\begin{array}{l}\text { Yes, but single } \\
\text { stand } \\
\text { optimisation } \\
\text { will also be } \\
\text { analysed }\end{array}$ & $\begin{array}{l}\text { Case study } \\
\text { area/Forest } \\
\text { type }\end{array}$ & Yes & No \\
\hline $\begin{array}{l}\text { Kupolis } \\
\text { (LIT) }\end{array}$ & $\begin{array}{l}\text { State forest } \\
\text { cadastre data, } \\
\text { available from } \\
\text { Lithuanian State } \\
\text { Forest Service }\end{array}$ & $\begin{array}{l}\text { No (each stand } \\
\text { has unique } \\
\text { properties) }\end{array}$ & - & No & $\mathrm{No}^{d}$ \\
\hline $\begin{array}{l}\text { EFISCEN- } \\
\text { space } \\
(\mathrm{NL})\end{array}$ & $\begin{array}{l}\text { GIS datasets from } \\
\text { multiple sources } \\
\text { (mainly developed } \\
\text { by Wageningen } \\
\text { University and } \\
\text { Research) }\end{array}$ & $\begin{array}{l}\text { Yes (Each } \\
\text { inventory plot } \\
\text { is individually } \\
\text { projected. } \\
\text { However, each } \\
\text { plot represents } \\
\text { a stratum.) }\end{array}$ & $\begin{array}{l}\text { Based on } \\
\text { NFI strata }\end{array}$ & $\begin{array}{l}\text { The } \\
\text { information is } \\
\text { not used in the } \\
\text { simulation, } \\
\text { inventory data } \\
\text { resolution too } \\
\text { low on stand } \\
\text { scale }\end{array}$ & $\mathrm{No}^{d}$ \\
\hline $\begin{array}{l}\text { SADfLOR } \\
\text { (POR) }\end{array}$ & GIS & $\begin{array}{l}\text { No, but } \\
\text { individual } \\
\text { stands may be } \\
\text { aggregated into } \\
\text { larger analysis } \\
\text { areas if needed }\end{array}$ & - & Yes & $\begin{array}{l}\text { Yes. The information } \\
\text { may be used in model } \\
\text { building to generate } \\
\text { spatial conditions' } \\
\text { requirements to } \\
\text { address ES other than } \\
\text { timber. It may be used } \\
\text { further to interpret } \\
\text { solutions when model } \\
\text { solving }\end{array}$ \\
\hline $\begin{array}{l}\text { Sibyla } \\
\text { (SVK) }\end{array}$ & $\begin{array}{l}\text { GIS/National } \\
\text { Forest Centre }\end{array}$ & $\begin{array}{l}\text { No (stand level } \\
\text { approach) }\end{array}$ & - & No & No \\
\hline
\end{tabular}




\begin{tabular}{|l|l|l|l|l|l|}
\hline $\begin{array}{l}\text { Heureka } \\
\text { and } \\
\text { HoldSim } \\
\text { (SWE) }\end{array}$ & $\begin{array}{l}\text { SLU } \\
\text { Forest Agency } \\
\text { Land Survey }\end{array}$ & $\begin{array}{l}\text { No (each stand } \\
\text { has unique } \\
\text { properties) }\end{array}$ & - & $\begin{array}{l}\text { Yes, in the } \\
\text { sense that } \\
\text { location of } \\
\text { stand vs. } \\
\text { property is } \\
\text { used. }\end{array}$ & No $^{\text {d }}$ \\
\hline $\begin{array}{l}\text { ETÇAP } \\
\text { (TUR) }\end{array}$ & $\begin{array}{l}\text { Forest inventory } \\
\text { plots and } \\
\text { GIS from the } \\
\text { General } \\
\text { Directorate of } \\
\text { Forestry }\end{array}$ & $\begin{array}{l}\text { No (each stand } \\
\text { has unique } \\
\text { properties) }\end{array}$ & - & Yes & $\begin{array}{l}\text { Yes, the adjacency is } \\
\text { created within the DSS } \\
\text { and the output is fed } \\
\text { back to GIS for } \\
\text { graphical/spatial } \\
\text { analysis }\end{array}$ \\
\hline
\end{tabular}

a Initially, but single stand optimisation/heuristics is explored later.

${ }^{\mathrm{b}}$ However, only when all stand site and management variables are identical.

c Not in the standard Remsoft Woodstock DSS optimiser, but will be explored in the Spatial Optimiser.

${ }^{d}$ The DSS as such is non-spatial. Spatial analyses of landscape patterns are carried out in GIS as post analyses of simulations. 


\section{References}

Bergh J, Freeman M, Sigurdsson B, Kellomäki S, Laitinen K, Niinistö S, Peltola H, Linder S (2003) Modelling the short-term effects of climate change on the productivity of selected tree species in Nordic countries. For Ecol Manage 183: 327-340. https://doi.org/10.1016/S0378-1127(03)00117-8

Bergh J, McMurtrie RE, Linder S (1998) Climatic factors controlling the productivity of Norway spruce: A model-based analysis. For Ecol Manage 110: 127-139. https://doi.org/10.1016/S03781127(98)00280-1

Botequim B, Zubizarreta-Gerendiain A, Garcia-Gonzalo J, Silva A, Marques S, Fernandes P, Pereira J, Tomé $M$ (2015) A model of shrub biomass accumulation as a tool to support management of Portuguese forests. iForest 8: 114-125. https://doi.org/10.3832/ifor0931-008

de Bruin JO, Hoogstra-Klein MA, Mohren GMJ, Arts BJM (2015) Complexity of forest management: exploring perceptions of Dutch forest managers. For 6 (9): 3237-3255.

https://doi.org/10.3390/f6093237

de Bruin JO, Kok K, Hoogstra-Klein MA (2017) Exploring the potential of combining participative backcasting and exploratory scenarios for robust strategies: Insights from the Dutch forest sector. For Policy Econ 85: 269-282. https://doi.org/10.1016/j.forpol.2017.06.007

Canton A, Pettenella D (2010) Family forest owners' motivations in forest management activities: a case study in Recoaro Terme municipality (north-east Italy). Forest@ 7: 44-57.

https://doi.org/10.3832/efor0618-007

Clerkx A, Hengeveld G, Schelhaas M, Helmink A (2016) Boseigendom in Twente en Salland: resultaten van een enquête onder kleine boseigenaren in Twente en Salland. Alterra-rapport 2731. AlterraWageningen University and Research, Wageningen.

Eggers J, Holmström H, Lämås T, Lind T, Öhman K (2015) Accounting for a diverse forest ownership structure in projections of forest sustainability indicators. For 6: 4001-4033.

https://doi.org/10.3390/f6114001

Eggers J, Lämås T, Lind T, Öhman K (2014) Factors influencing the choice of management strategy among small-scale private forest owners in Sweden. For 5: 1695-1716.

https://doi.org/10.3390/f5071695

Fabrika M, Ďurský J (2005) Algorithms and software solution of thinning models for SIBYLA growth simulator. J For Sci 51(10):431-445.

Fabrika M, Pretzsch H (2013) Forest ecosystem analysis and modelling. Technical University in Zvolen, Zvolen.

Hoogstra-Klein MA (2016) Exploring the financial rationales of Dutch forest holdings and their relation with financial results. Eur J For Res 135(6): 1025-1036. https://doi.org/10.1007/s10342-0160991-6

Hoogstra-Klein M, Burger M (2013) Rational versus adaptive forest management planning: exploratory research on the strategic planning practices of Dutch forest management organizations. Eur J For Res 132 (5-6): 707-716. https://doi.org/10.1007/s10342-013-0707-0 
Montesarchio M, Mercogliano P, Manzi MP, Buccignani E (2012) A sensitivity study with the RCM COSMO CLM over the north and center Italy. CMCC Research Papers Issue RP0143.

http://dx.doi.org/10.2139/ssrn.2195479

Mozgeris G, Brukas V, Stanislovaitis A, Kavaliauskas M, Palicinas M (2016) Owner mapping for forest scenario modelling - A Lithuanian case study. For Policy Econ 85: 235-244.

http://dx.doi.org/10.1016/j.forpol.2016.02.002

Mozzato D, Gatto P (2016) Determinants, attitudes and willingness of private forest owners to produce goods and services: A review of the international literature. Forest@ 13(1): 18-30.

https://doi.org/10.3832/efor1751-013

Pretzsch H (2009) Forest dynamics, growth, and yield. A review, analysis of the present state, and perspective. Springer, Berlin and Heidelberg. https://doi.org/10.1007/978-3-540-88307-4_1

Pretzsch H, Biber P, Ďurský J (2002) The single tree-based stand simulator SILVA: construction, application and evaluation. For Ecol Manag 162:3-21. https://doi.org/10.1016/S0378-1127(02)000476

Ray D, Xenakis G, Tene A, Black K (2009) Developing a site classification system to assess the impact of climate change on species selection in Ireland. Irish For 66 (1\&2): 101-122.

Schelhaas MJ, Clerkx APPM, Daamen WP, Oldenburger JF, Velema G, Schnitger P, Schoonderwoerd H, Kramer H (2014) Zesde Nederlandse bosinventarisatie: methoden en basisresultaten. AlterraWageningen University and Research, Wageningen. 